\title{
Inositol phosphates: health implications, methods of analysis, and occurrence in plant foods
}

\begin{abstract}
Quynh H. Duonga, Karen G. Lapsleyb and Ronald B. Pegg ${ }^{\mathrm{a}^{*}}$
aDepartment of Food Science \& Technology, College of Agricultural and Environmental Sciences, The University of Georgia, 100 Cedar Street, Athens, GA, 30602, USA

${ }^{\mathrm{b}}$ Almond Board of California, 1150 Ninth Street, Suite, 1500, Modesto, CA, 95354, USA

*Corresponding author: Dr. Ronald B. Pegg, Department of Food Science \& Technology, The University of Georgia, 100 Cedar Street, Athens, GA 30602-2610, USA. Tel: (706) 542-1099; Fax: (706) 542-1050; E-mail: rpegg@uga.edu

DOI: $10.31665 / J F B .2018 .1126$

Received: January 05, 2018; Revised received \& accepted: January 15, 2018

Citation: Duong, Q.H., Lapsley, K.G., and Pegg, R.B. (2018). Inositol phosphates: health implications, methods of analysis, and occurrence in plant foods. J. Food Bioact. 1: 41-55.

Abstract

Inositol phosphates (InsPs), especially myo-inositol hexakisphosphate ( $\left.\operatorname{lns}_{6}\right)$, are important binders of phosphorus and minerals in plant seeds. However, they have long been considered as anti-nutritional components of plant foods due to their possible negative effects on the absorption of minerals and proteins in mammals. On the other hand, recent findings have found InsPs to be ubiquitous in eukaryote cells and actively participating in multiple cell functions. In vivo and in vitro studies have also documented the preventive potential of these compounds against the development of a wide range of diseases. In light of these findings, interest in the relationship between these compounds and human health has been renewed. It is suggested that the interactions of InsPs with other nutrients in the gut are complex, that the absorption of dietary InsPs might be implied but is not certain, and that the disease fighting capabilities of InsPs hold both promises and limitations. At the same time, the analysis of these compounds in foods and biological samples still faces many challenges, calling for more advanced modification and developments in the future.
\end{abstract}

Keywords: Inositol phosphates (InsPs); Phytic acid; Phytate; Antioxidant; Chemoprevention.

\section{Introduction}

Phytic acid (myo-inositol hexakisphosphate, $\mathrm{Ins}_{6}$ ), also frequently referred to by its salt form phytate and phytin, is an important component of plant seeds and a controversial constituent in the human diet. The compound is commonly consumed in high amounts from staple cereals and legumes, in which it serves as the main phosphorus reservoir and one of the major binders of minerals for the seeds (Kornegay, 2000). While plant seeds possess endogenous phytases to hydrolyze $\mathrm{InsP}_{6}$ and its salts upon germination, humans produce very minimal amount of this enzyme group endogenously and must rely on microbial phytases, which are often insufficient for the complete digestion of the $\mathrm{InsP}_{6}$ content in foods (Lopez et al., 2002). At the $\mathrm{pH}$ levels of the human digestive tract, $\mathrm{InsP}_{6}$ can form insoluble salts and complexes with minerals and macronutrients, rendering these nutrients unavailable for absorption or other activities (Konietzny et al., 2006; Kumar et al., 2010). As a result, this compound has been implied to be an antinutrient even though its negative effects have not been well described in vivo. On the other hand, emerging research is showing that $\mathrm{InsP}_{6}$ as well as lower forms of inositol phosphates (InsPs), including myo-inositol mono-, bis-, tris-, tetrakis-, and pentakisphosphate ( $\left.\operatorname{InsP}_{1-5}\right)$, are widely present in eukaryote cells and may have important physiological functions (Irvine and Schell 2001; Sauer and Cooke 2010; Shears 1998). InsP ${ }_{6}$ has also been found to have anti-inflammatory and anticancer effects in various types of cell lines (Vucenik et al., 2004). At the same time, it is still unclear whether dietary InsPs can be absorbed in the human digestive tract and mobilized for metabolic activities, as no carrier for these compounds has been 
<smiles>O[C@H]1[C@H](O)[C@H](O)[C@H](O)[C@@H](O)[C@H]1O</smiles>

Figure 1. Chemical structure of myo-inositol.

detected, but some studies have reported intracellular InsPs to be dependent on extracellular InsPs (Grases et al., 2002). Overall, there remain many questions on the role of dietary InsPs in human health and disease prevention. This contribution aims to provide an overview on the development of the understanding pertaining to the relationship between dietary InsPs and human health, the efforts to quantify InsPs in major food products, as well as the on-going challenges that are important to the study of these compounds.

\section{Chemical properties of inositol phosphates}

InsPs refer to the phosphorylated compounds of inositol (cyclohexane-1,2,3,4,5,6-hexol), in which one or more hydroxyl moieties on the six-carbon ring of inositol is replaced with a phosphate group. Inositol exists in nine possible stereoisomers, of which myo-inositol (Figure 1) is the most abundant species found in nature. As a result, "inositol phosphate" commonly refers to a phosphorylated myo-inositol. Depending on the number of phosphate groups on the inositol ring, a compound in this family can be referred to as myo-inositol mono-, bis-, tris-, tetrakis-, pentakis, or hexakisphosphate $\left(\operatorname{InsP}_{1-6}\right)$. All lower inositol phosphates $\left(\operatorname{InsP}_{1-5}\right)$ display isomerism.

To date, myo-inositol hexakisphosphate ( $\operatorname{InsP}_{6}-$ Figure 2 ), also commonly referred to as phytic acid, has garnered the most attention due to its capability to chelate mineral cations in the digestive system and its high apparent concentration in plant seeds. The compound is sterically stable when one phosphate is in the axial position and five phosphates are in the equatorial position (1ax/5eq) (Bohn et al., 2008). Depending on the $\mathrm{pH}$ of the medium and the presence of other cations, $\mathrm{InsP}_{6}$ can invert into the sterically hindered form, in which one phosphate is in the equatorial position and five are in the axial position (5ax/1eq). Under the effect of heat, acid treatment, or enzymatic activity by the enzyme group phytase, $\mathrm{InsP}_{6}$ can be dephosphorylated into $\mathrm{InsP}_{1-5}$ as well asmyo- inositol.

As indicated by their prefixes, the phosphate groups of $\mathrm{InsP}_{2-6}$ are not internally connected and these compounds are polydentate ligands (Bohn et al., 2008). InsPs are capable of binding mineral cations such as calcium, zinc, copper, cobalt, manganese, iron, and magnesium, forming the salt phytate (phytin, if it is a mixed salt). The binding capability varies among InsPs and is dependent on the type of mineral. For example, in vitro studies at $\mathrm{pH} 3$ to 8 have found that InsPs typically have a greater affinity with copper, zinc, and nickel than with other mineral cations (Persson et al., 1998; Tsao et al.,1997; Vasca et al., 2002). InsP ${ }_{6}$ and InsP $_{5}$ have higher binding strength than $\mathrm{InsP}_{3}$ and $\mathrm{InsP}_{4}$, and the distribution of the phosphate groups on the inositol ring also differentiates binding affinity among stereoisomers. InsPs and their salts with monovalent cations, such as sodium and potassium, are typically water soluble, while salts with multivalent cations have varying degrees of solubility depending on the $\mathrm{pH}$ of the environment and the presence of competing cations.

At low $\mathrm{pH}$ levels, $\mathrm{InsP}_{6}$ can bind to the cationic groups of pro-<smiles>O=P(O)(O)O[C@H]1[C@H](OP(=O)(O)O)[C@@H](OP(=O)(O)O)[C@H](OP(=O)(O)O)[C@@H](OP(=O)(O)O)[C@H]1OP(=O)(O)O</smiles>

Figure 2. Chemical structures of myo-inositol hexakisphosphate $\left(\operatorname{InsP}_{6}\right)$ or phytic acid.

teins and forms insoluble complexes (Ellis and Morris, 1983). This binding might include interactions with the $\alpha-\mathrm{NH}_{2}$ terminal group, the $\varepsilon-\mathrm{NH}_{2}$ group of lysine, the imidazole group of histidine, and the guanidyl group of arginine. At $\mathrm{pH}$ levels higher than these proteins' isoelectric points, soluble protein-mineral-phytate complexes may form (Gemede, 2014).

\section{The physiological roles of extraneous inositol phosphates}

InsPs are ubiquitous in seeds, which include cereals, legumes, and nuts that are frequent components in human and animal diets. InsP $\mathrm{P}_{6}$ is said to typically comprise $>85 \%$ of InsP composition and serves as a mineral binder, phosphorus source, and energy source for the seed (Kornegay, 2000). During germination, phosphorus and minerals will be released from phytate by phytases. Many animals, especially ruminant types, have been found to depend on microbial phytases in the gut for InsP catabolism. In humans, phytase secretion appears to be limited, and microbial phytases in the large intestine are likely to be important to the digestion of InsPs (Iqbal et al.,1994; Lopez et al., 2002; Schlemmer et al.,2009).

\subsection{Inositol phosphates as an antinutrient}

Dietary InsPs are often viewed as undesirable due to their capability to chelate mineral cations and to form complexes with protein, carbohydrate, and lipid, which reduce the availability of these nutrients in the body (Kumar et al., 2010). InsP $\mathrm{P}_{6}$ and $\mathrm{InsP}_{5}$ are the most abundant InsPs in foods and are also the InsPs with the strongest binding capabilities. In many countries where whole grain cereals and legumes are staples, InsPs, along with other components, such as inorganic phosphates, polyphenols, and nondigestible fiber, may exacerbate on-going nutrient deficiency problems (Schlemmer et al., 2009). Of most concern are the potential adverse effects on the absorption of zinc and iron-two minerals with prevalent deficiencies around the world-as well as calcium and magnesium. Furthermore, the formation of insoluble phytates/ phytins and complexes also render phosphorus unavailable for the body (Konietzny et al., 2006).

Zinc is strongly sequestered by $\operatorname{InsP}_{6}$, and zinc phytate forms readily within the $\mathrm{pH}$ range of 3 to 7 , which includes the $\mathrm{pH}$ range of the duodenum, where the absorption of this mineral occurs (Persson et al., 1998). Among $\mathrm{InsP}_{3-6}$, only $\mathrm{InsP}_{6}$ and $\mathrm{InsP}_{5}$ have been found to exert a significant inhibitory effect on zinc absorption (Lönnerdal et al.,1989). The World Health Organization (WHO) 
considers zinc absorption to be low when it is $<15 \%$ (compared to $\sim 30 \%$ in most diets), which can be caused by a phytate:zinc mole ratio of more than 15 (World Health Organization, 2014). On the other hand, the International Zinc Nutrition Consultative Group (IZiNCG) set the low level of zinc absorption to be $18 \%$ in adult men and $25 \%$ in adult women, which may occur when the phytate:zinc mole ratio is more than 18 (IZiNCG et al., 2004). The difference between these prediction models highlights the need for more human studies on this topic. It is notable that other than the phytate:zinc mole ratio, the level of inhibition can also be affected by the presence of secondary cations, such as calcium and magnesium ions, as secondary cations can either displace $\mathrm{Zn}^{2+}$ from InsPs' binding sites or form insoluble phytins in conjunction with $\mathrm{Zn}^{2+}$ (Forbes et al., 1984; Gemede, 2014; Walter et al., 2000). The impact of these interactions in humans is not yet fully understood, and while IZiNCG currently considers calcium and protein to be insignificant factors in predicting zinc absorption, the organization also emphasizes that more studies on the interactions of these nutrients with zinc and phytate during the digestion process are necessary. For example, in a study with forty human subjects, Fredlund et al. (2006) experimented by adding various levels of $\mathrm{InsP}_{6}$ ranging from 0 to $1344 \mu \mathrm{mol}$ to a low-phytate bread roll containing $47 \mu \mathrm{mol}$ zinc and $66.6 \mathrm{mmol}$ calcium. The author found that zinc absorption decreased from $21.5 \%$ to $14.45 \%$ when the $\operatorname{InsP}_{6}$ content in the roll reached a phytate:zinc mole ratio of 5.7:1 $(260 \mu \mathrm{mol}$ $\mathrm{InsP}_{6} /$ roll). By the time the phytate:zinc mole ratio surpassed 15:1, the overall zinc absorption was only $7.4 \%$, which was much lower than what was predicted by WHO and IZiNCG.

Of the two types of dietary iron, heme and non-heme iron, dietary $\mathrm{InsP}_{6}$ and $\mathrm{InsP}_{5}$ have been implicated with decreased nonheme iron absorption (Reddy et al., 1996; Sandberg et al., 1999). As heme iron only comes from animal foods, there is concern for populations whose diet contains little to no meat, as a high proportion of phytate-containing grains may experience exacerbated iron deficiency. With regard to non-heme iron, $\mathrm{InsP}_{4}$ and $\mathrm{InsP}_{3}$ did not exhibit an inhibitory effect on absorption when they were the only InsPs in foods, but when present in combination with $\mathrm{InsP}_{5}$ and $\mathrm{Ins}_{6}$, the inhibitory efficacy was stronger than when only $\mathrm{Ins}_{5}$ and Ins $_{6}$ were in the samples (Sandberg et al., 1999). This finding suggested that there could be a synergistic effect between InsP $\mathrm{P}_{5-6}$ and lower InsPs, where an iron ion at a high degree of covalency could bind with two or three different InsP molecules simultaneously, some of which could be InsP $\mathrm{P}_{3-4}$. The authors also remarked that different isomeric forms of $\mathrm{InsP}_{3-4}$ could have exerted varying levels of effect in this case, as myo-1,2,6-inositol trisphosphate and InsPs with the 1,2,3-trisphophate grouping can form more stable complexes with $\mathrm{Fe}^{3+}$. On the other hand, the negative effect of InsPs on iron absorption was not found in all studies, showing that this effect can be influenced by factors other than the levels of InsPs and iron that are yet to be identified (House and Welch, 1987; Simpson et al., 1981). Hallberg et al. (1987) have observed that iron phytate in foods can be present in notable quantities as monoferric phytate, which is well absorbed. Yet, when sodium phytate or a mixture of magnesium phytate and potassium phytate were added to the samples, iron absorption decreased, likely due to the formation of insoluble phytins.

Similarly, the inhibitory effect of phytate on calcium and magnesium ion absorption may be suggested, but experimental values have been inconclusive (Crea et al.,2006). Miyazawa et al. (1996) reported a negative effect on the apparent absorption of magnesium but not that of calcium in rats. Lönnerdal et al. (1989) observed inhibition of calcium ion uptake by $\operatorname{InsP}_{6}$ and $\mathrm{InsP}_{5}$, but not by $\mathrm{InsP}_{4}$ and $\mathrm{InsP}_{3}$. It is also unclear whether lowered absorption of these minerals actually translates into health concerns. A sur- vey study by López-González et al. (2008) assessed that dietary phytate is not a risk factor of osteoporosis, and increasing phytate consumption can even be linked with higher bone mineral density.

In pig and poultry nutrition, phytase supplementation to the fodder has been demonstrated to improve amino acid digestibility, which implied that InsPs impedes amino acid absorption in the gut (Selle et al., 2000). The form of InsP can influence this effect, as the magnesium-potassium salt of Ins $_{6}$ showed a higher inhibitory strength than free $\mathrm{InsP}_{6}$ (Onyango et al., 2008). InsP ${ }_{6}$ has also been shown to inhibit several digestive enzymes such as $\alpha$-amylase, lipase, and various proteinases (e.g., pepsin, trypsin, chymotrypsin) in fish and poultry (Denstadli et al., 2006; Khan and Ghosh, 2013; Liu et al., 2010). These effects may be explained by the non-specific bindings of InsPs with cationic moieties of amino acids and proteins, followed by the precipitation of these complexes at low $\mathrm{pH}$ levels. In additional, ternary protein-mineral-phytate complexes may form, with a divalent mineral cation serving as the cationic bridge between phytate and an anionic moiety of a protein. Examples of these anionic moieties include the unprotonated imidazole group of histidine and the ionized carboxyl groups of other proteins (Selle et al., 2000). The solubility of these complexes is also dependent on $\mathrm{pH}$. Among soluble mineral-phytate complexes and ternary protein-mineral-phytate complexes, an equilibrium may exist. Preference for either type of complex is influenced by ion concentrations as well as the degree of strain placed on the inositol ring by each type of complex (Champagne et al., 1990). For instance, the equilibrium involving calcium ion can be illustrated as follows:Protein $+\mathrm{Ca}+$ Phytate $\square[$ Protein-Ca-Phytate $] \square[\mathrm{Ca}-$ Phytate] + Protein

From these perspectives, InsPs appear to be generally antinutritional. Breeding, genetic modification, germination, soaking, heat treatment, and fermentation are methods that have been investigated and recommended to reduce InsP levels in plant foods. On the other hand, it must be noted that InsPs are only some among many dynamic factors that can interact with each other in the digestive tract to affect mineral absorption. For instance, the inhibitory effect of InsPs on zinc ion absorption can be reduced with dietary protein, while administration of ascorbic acid with a phytate-containing meal has been demonstrated to improve iron absorption (Davidsson et al., 1994; Sandström et al., 1989; Siegenberg et al., 1991). Regarding magnesium, many unrefined plant foods rich in phytate are also rich in this mineral, and it has been argued that the eventual amount of magnesium absorbed from these foods may be equal to or higher than from low-phytate containing foods (Levrat-Verny et al., 1999). In rats, resistant starch has been shown to be able to negate the effects of phytic acid on the absorption of iron, zinc, and copper (Lopez et al., 1998). The authors suggested that a potential mechanism behind this effect is the production of short-chain fatty acids (SCFA) during the fermentation process, which adjusts the $\mathrm{pH}$ of the environment. Additionally, these SCFA can compete with InsPs to form complexes with mineral cations, which may be low in charge and can enter the enterocytes.

The dynamic of $\operatorname{InsP}_{6}$ protonation and complex formation is difficult to study and summarize because it is strongly affected by several factors at the same time. The molecule can donate up to twelve protons and exhibits multiple acid dissociation constants across a wide range of $\mathrm{pH}$ values, depending on the ionic strength of the medium and the presence of other ions (Crea et al., 2008; Heighton et al., 2008). The stability and solubility of the complexes formed between InsP ${ }_{6}$ and any type of ion are also affected by these aspects. Meanwhile, the condition of the digestive system can vary strongly. The average $\mathrm{pH}$ level in the human gastrointestinal tract varies between 1 and 7.5, with possible modifications caused by foods consumed in the meal (Evans et al., 1988; Kong 
and Singh, 2008).Taking these effects into account, improving mineral absorption by maintaining a diverse diet might be a more positive approach to avoid mineral deficiency than reducing InsP contents in foods. Some amount of dietary InsPs may be important, because InsPs' general capability to chelate mineral ions may help reduce the absorption of toxic trace elements such as cadmium and lead (Schlemmer et al., 2009). Moreover, new findings on the roles of InsPs in normal body functions and disease states propose that InsPs may be essential and beneficial to human health.

\subsection{Inositol phosphates as participants in cell functions and the role of dietary inositol phosphates}

In recent decades, insights on the importance of InsPs to eukaryote cells have emerged.Ins $(1,4,5) \mathrm{P}_{3}, \operatorname{Ins}(1,3,4) \mathrm{P}_{3}, \operatorname{Ins}(1,3,4,5) \mathrm{P}_{4}$, and Ins $(1,3,4,5,6) \mathrm{P}_{5}$ have been found to work dynamically in different $\mathrm{Ca}^{2+}$ signaling pathways (Irvine and Schell, 2001; Lückhoff and Clapham, 1992; Streb et al.,1983; Tsubokawa et al., 1996; Vajanaphanich et al., 1994). Both myo-inositol-1,3,4,5,6-pentakisphosphate and $\mathrm{InsP}_{6}$ have important roles in mRNA export, genomic stability, and apoptosis (Loss et al.,2013; Majerus et al., 2008; Monserrate and York, 2010). More than half of the 63 possible InsP isomers have been identified in various types of cell (Irvine and Schell, 2001; Shears 1998). Different reactions by InsP pools to specific stimulations imply that these compounds may actually have many more functions to be investigated (Irvine and Schell, 2001; Otto et al., 2007).

Many different pathways for the synthesis of InsPs by cells have been discovered in plants, molds, and animals. Phosphatidylinositol 4,5-bisphosphate can be hydrolyzed into $\operatorname{Ins}(1,4,5) \mathrm{P}_{3}$, which, together with inositol, can be rapidly converted by plant and slime mold cells into other InsPs through a series of positionally selective and sequential kinase reactions. In mammalian cells, glucose6-phosphate is believed to serve as the precursor for Ins $(1,4,5)$ $\mathrm{P}_{3}$, providing a second pathway that is independent of inositol lipid metabolism (Irvine and Schell, 2001; Sasakawa et al., 1995). Yet, both pathways have been found to proceed at extremely slow rates, despite some evidences indicating that the conversion of Ins $(1,4,5) \mathrm{P}_{3}$ into InsP ${ }_{6}$ in cells can be very fast. The synthesis of InsPs in animals remains an ongoing topic for examination.

It is also worthwhile to mention a class of molecules closely related to InsPs, namely inositol pyrophosphates (PPx-InsPs). Using $\mathrm{InsP}_{6}$ as precursor, these compounds are synthesized by linking additional phosphate(s) to an existing phosphate group on the inositol ring via pyrophosphate bond(s) (Williams et al., 2015). So far, a few members of this family have been described, including several stereoisomers of triphosphoinositol pentakisphosphate $\left(\mathrm{PPP}-\mathrm{Ins}_{5}\right)$, diphosphoinositol pentakisphosphate (PP-InsP ${ }_{5}$, bis-disphosphoinositol trisphosphate ( $\left.(\mathrm{PP})_{2}-\mathrm{InsP}_{3}\right)$, and bisdiphosphoinositol tetrakisphosphate $\left((\mathrm{PP})_{2}-\mathrm{InsP}_{4}\right)$. These compounds are sometimes abbreviated as $\operatorname{Ins}_{7}$ and $\operatorname{InsP}_{8}$, although these names fail to signify the important presence of the high-energy diphosphate or triphosphate chain(s). Similar to InsPs, PPx-InsPs are ubiquitous in eukaryote cells and have been inferred to participate in many cell functions, including energy sensing, inorganic phosphate sensing, and immune response (Williams et al., 2015; Wilson et al.,2013). Because PPx-InsPs are present in very small amounts, dietary PPx-InsPs are unlikely to be absorbed at significant levels by the human body. Consequently, the body may have to rely on the synthesis of these compounds from InsP ${ }_{6}$.

At the moment, the contribution of exogenous sources to the maintenance of InsP pools in the human body is also not fully understood. Depending on the $\mathrm{pH}$, InsPs can be negatively charged, which hinder their absorption in the gut. The small size of the inositol ring also leads to a high-charge density. So far, no carrier has been detected for InsPs in the human digestive track. Nevertheless, existing studies suggest that cellular intake of these compounds is possible and that InsP levels in the body are influenced by dietary intakes.

Grases et al. (2002) have demonstrated that in rats fed with different levels of InsP $\mathrm{P}_{6}$, the concentration of extracellular $\operatorname{InsP}_{6}$ (in plasma and interstitial fluid) increases with dietary intake, while the concentration of extracellular $\mathrm{Ins}_{3}$ is not significantly affected. In the same study, human epithelial and mesenchymal cells grown in culture media with inositol reached an $\mathrm{InsP}_{6}$ concentration of $\sim 16$ $\mu \mathrm{mol} / \mathrm{kg}$, whether or not Ins $\mathrm{P}_{6}$ was supplied in the media, indicating the cells' capability to synthesize $\mathrm{InsP}_{6}$ from inositol. When these cells were treated with $1.8 \mathrm{mM} \mathrm{InsP}_{6}$ for 1 hour, the intracellular InsP ${ }_{6}$ content did not change, whereas the intracellular $\operatorname{InsP}_{3}$ content doubled. This effect was attributed to dephosphorylation activity by the cell, which varies in rate depending on cell type (Vucenik and Shamsuddin, 1994). The concentrations of $\operatorname{InsP}_{3}$ and $\mathrm{InsP}_{6}$ in plasma fluid and in cells were thus concluded to have partial links to exogenous InsP $_{6}$

By monitoring InsP ${ }_{6}$ intake through diet and administration of oral doses, Grases et al.(2001) showed that the plasma level and urinary excretion of Ins $\mathrm{P}_{6}$ in humans are affected by oral ingestion in both the short and long term. A positive correlation was detected between these two measurements. Under the test conditions, the urinary excretion levels were always much lower than the intake level and would plateau at a certain $\operatorname{InsP}_{6}$ dose, indicating that humans have a limited ability to absorb and/or excrete $\operatorname{InsP}_{6}$. Another study also found that $\mathrm{InsP}_{6}$ absorption is independent of the condition of the stomach (whether empty, empty with an alkalinizer, or full), suggesting that absorption may occur during intestinal transit (Grases et al., 2006).

Using the ileostomy model, Agte et al. (2005) were able to describe the apparent absorption of all six InsPs from traditional Indian vegetarian meals. The level of apparent phosphorus absorption was found to increase from InsP ${ }_{6}$ to InsP ${ }_{1}$, although it must be noted that higher InsPs contributed more phosphorus than lower forms due to their higher relative abundance. $\operatorname{InsP}_{1}$, which was consumed in minimal amount, was completely degraded, while absorption for phosphorus from InsP $\mathrm{P}_{2}$ only reached $64 \%$. For $\mathrm{InsP}_{3-6}$, which were responsible for $\sim 96 \%$ of the phosphorus amount bound by InsPs in these meals, the \% phosphorus absorption varied between 29 and 39. The net absorption of InsP phosphorus from these meals was $35 \%$. As only three subjects were able to complete the trial (two men and one woman), this study was severely limited by sample size. For InsP $\mathrm{P}_{1-5}$ output results, it was not possible to distinguish between the amount of InsPs retained from the original meals and the quantity of InsPs generated by the degradation of higher forms. Nevertheless, these results still suggest that InsPs might be degraded and absorbed at a significant degree in the human digestive system.

In a controlled trial with Korean women, Joung et al.(2007) found that the degradation of dietary $\mathrm{InsP}_{5}$ and $\mathrm{InsP}_{6}$ is greater in elderly women compared to that in young women. A rise in dietary phytate levels also induced a significant rise in phytate excretion in young women, but not in elderly women. In both subject groups, phosphorus absorption was not affected when phytate became the main dietary phosphorus source. These results imply that the human body may have a mechanism to alter phytate degradation activity in the digestive tract according to its needs.

It is important to remember that biological samples are particularly complex to analyze, and some of the studies mentioned above used indirect assays for the measurement of InsPs, which might 
result in inaccurate detection. By using a specific assay, Letcher et al. (2008) have found $\mathrm{InsP}_{6}$ to be undetected in the serum and platelet-free plasma $\left(<1 \mathrm{nM} \operatorname{InsP}_{6}\right)$ as well as in the urine $(<5 \mathrm{nM}$ Ins $\mathrm{P}_{6}$ ), suggesting that $\mathrm{Ins}_{6}$ was unlikely to be absorbed in the gut. Wilson et al. (2015) also reached this conclusion when they applied a different specific assay on the same types of samples.As a result, the absorption of dietary InsPs still requires further investigation, especially with direct analysis methods.

\subsection{Inositol phosphates' disease fighting abilities}

Recently, many findings have highlighted InsPs' disease fighting capabilities. These include the prevention of pathological calcification, antioxidative activities, and anticancer effects. $\mathrm{InsP}_{6}$ was first considered as an agent against pathological calcification in hypercalcuria patients due to its possible interference with calcium absorption (Nassim and Higgins, 1965). Later, InsP $_{6}$ was found to have strong crystallization inhibiting property against these unwanted calcium salts, which allows it to be effective even at a relatively low concentration. Experimentation with synthetic urine has demonstrated that phytic acid can completely stop the growth of calcium oxalate stones, which is the predominant form of kidney stones (Costa-Bauzá et al., 2005). In animal models, InsP ${ }_{6}$ has been shown to reduce calcium deposition in kidneys and related organs, as well as slow down the growth of dystrophic calcification plaques in the cardiovascular system (Grases et al., 1996; Grases et al., 2004b). In humans, lower urinary concentration of $\operatorname{InsP}_{6}$ has been associated with active calcium oxalate stone-formers, and high intake of dietary $\mathrm{Ins}_{6}$ has been suggested to decrease the risk of kidney stones in these subjects (Conte et al., 1999; Curhan et al.,2004; Grases et al., 2000). As a crystallization inhibitor, $\mathrm{InsP}_{6}$ may contribute to the prevention of sialolithiasis and dental calculus formation (Grases et al., 2009; Grases et al.,2003).

InsPs may exert their antioxidative property via generic as well as specific chelating activities. Other than binding iron and copper ions in general, some InsPs has the 1,2,3-trisphosphate arrangement which, upon interacting with $\mathrm{Fe}^{3+}$, would occupy all six coordination sites of this ion with hydroxyl groups (Phillippy and Graf, 1997). As a result, these compounds inhibit iron's catalytic action on lipid peroxidation and hydroxyl radical formation in the Fenton reaction. A similar effect has been observed with ferrous ion. Phytate can be used to prevent myoglobin oxidation in meat processing, which changes the color of homogenized meat from red to brown (Park et al., 2004; Stodolak et al.,2007). From in vitro studies on rodent liver, Rimbach and Pallauf (1998) did not find phytate to have the capability to reduce oxidation markers in rats, while Bhowmik et al. (2017) found that $\mathrm{InsP}_{6}$ significantly reduced the oxidative stress caused by iron overload in mice. Intravenously-injected phytate appears to provide some degree of myocardial protection to rats subjected to cardiac excision, but not to rat hearts that were removed from hypothermic storage (modeling a heart transplant) (Kazimoglu et al., 2004; Rao et al.,1991). These results suggest that InsPs' performance as antioxidants in vivo may be limited to specific working conditions and routes of administration (Iemma et al., 2007).

InsP $_{6}$ has demonstrated a remarkable preventive effect on tumor development in different cancer cell lines, namely blood, colon, liver, lung, mammary, melanoma, pancreas, prostate, skin, soft tissue, and uterine cervix (Vucenik and Shamsuddin, 2006). Multiple effects beyond antioxidant activity have been recognized, such as the inhibition of cell proliferation, metastasis, angiogenesis, and inflammation ( $\mathrm{Gu}$ et al., 2010;Kumar et al., 2004;Norazalina et al., 2010; Raina et al., 2013). $\operatorname{InsP}_{6}$ has been shown to support apoptosis as well as the differentiation and maturation of malignant cells, which can recover the normal phenotype (Deliliers et al., 2002; Shamsuddin and Yang, 1995; Singh et al., 2003; Vucenik et al.,2004). Some studies observed that Ins $\mathrm{P}_{6}$ enhances the activity of natural killer cells and reduces the depression of these cells by carcinogens (Baten et al., 1989; Zhang et al., 2005). These activities vary depending on dose, time, and the origin of the cells. A synergistic effect upon combination with inositol has also been suggested in a number of animal studies on different cancer types (Shamsuddin et al., 1989; Vucenik et al., 1995).

Dietary phytate exhibits an antineoplastic effect in non-ruminant animal models equally well whether consumed in a fluid or non-fluid system, highlighting the possibility of effective absorption mechanisms for extraneous InsPs that do not depend on microbial phytases. However, a human's ability to absorb InsPs cannot be directly extrapolated from rodent models because phytase activity in our tissue is $\sim 30$ times lower than that of rat tissues (Iqbal et al., 1994). On the other hand, it has been hypothesized that the anticancer activities of Ins $\mathrm{P}_{6}$ depend on the compound's dephosphorylation to lower InsPs, even though the exact metabolism pathways and mechanisms of action still need to be elucidated (Vucenik and Shamsuddin, 2006). From this point of view, extraneous InsP $\mathrm{P}_{1-5}$ may also play important roles against cancer.

In mouse, Ins $\mathrm{P}_{6}$ has demonstrated a protective effect against Alzheimer's disease by decreasing lipid peroxidation and increasing cytochrome oxidase levels in the brain (Anekonda et al., 2011). In the same study, the compound was found to prevent the apoptosis of neurons by protecting MC65 cells against cytotoxicity by amyloid- $\beta$ peptide. This action is opposite to the effect InsP $\mathrm{P}_{6}$ exerts on malignant cells, which has been described above, implying that $\mathrm{InsP}_{6}$ is likely to serve as an apoptosis modulator. Similar protective activities have also been observed in other cell conditions. In studying the rat mesencephalic dopaminergic cell line (N27), Xu et al. (2008) reported that Ins $\mathrm{P}_{6}$ decreased pathological apoptosis induced by 1-methyl-4-phenylpyridinium and increase cell viability, suggesting that Ins $\mathrm{P}_{6}$ may offer protective therapy for Parkinson's disease. In pig small intestines, InsP $_{6}$ was found to reduced cell proliferation, apoptosis, and cyclooxygenase- 2 expression, which are associated with inflammation (Silva et al., 2014a). The compound also protected cells against hypoxia-induced morphological changes. These effects were attributed to $\mathrm{Ins}_{6}$ 's antioxidant property, which may have inhibited the production of cytosolic reactive oxygen species. Notably, $\operatorname{InsP}_{6}$ from rice was found to be more efficient than $\mathrm{InsP}_{6}$ from corn, which was hypothesized by the authors to be due to the different numbers of sodium and water moieties attached to each $\operatorname{Ins}_{6}$ molecule between the two sources (i.e., $\mathrm{InsP}_{6} \cdot 12 \mathrm{Na} \cdot 8 \mathrm{H}_{2} \mathrm{O}$ from rice versus $\mathrm{InsP}_{6} \cdot 11 \mathrm{Na} \cdot 7 \mathrm{H}_{2} \mathrm{O}$ from corn).

Some positive effects of phytate on type- 2 diabetes mellitus have been suggested, as phytate intake has been found to negatively correlate with blood glucose response. In mice fed a highfat diet, $\mathrm{InsP}_{6}$ exerted an antihyperglycemic effect by regulating the activities of glucose-6-phosphatase, glucokinase, and phosphoenolpyruvate carboxykinase (Kim et al., 2010). Larsson et al. (1997) also demonstrated that InsP $_{6}$ may play a role in regulating insulin secretion, possibly by inhibiting the activity of serinethreonine protein phosphatases, thus opening intracellular calcium channels and leading to insulin release. Ins $\mathrm{P}_{5}$ could exert similar effects on calcium ion channels, but required a higher amount than InsP $\mathrm{P}_{6}$, while $\mathrm{InsP}_{4}$ was not able to provide any action of the type.

Jariwalla et al. (1990) reported phytate to significantly lower serum cholesterol and triacylglycerol levels. A lower serum zinc level and zinc-copper ratio were observed in conjunction with these effects. Zinc and copper ions share the same mucosal carrier systems, and excess zinc in the diet can lead to reduced copper 
absorption, which has been hypothesized to cause coronary heart disease (Klevay, 1975). Because $\mathrm{InsP}_{6}$ has a greater binding affinity for zinc than copper ions, its presence may have helped in lowering the zinc-copper ratio (Persson et al., 1998). However, in experimenting with rats fed a high-sucrose diet, Onomi et al. (2004) noted that the hepatic concentrations of total lipids and triacylglycerols, as well as the hepatic activity of glucose-6-phosphate dehydrogenase, were reduced when the sodium phytate level in the feed was as low as $0.02 \%$. Meanwhile, the serum zinc level was not affected until the sodium phytate content reached $2.5 \%$. These authors also detected reductions in cholesterol level and fatty acid synthetase activity, but the effects did not show a clear dose-dependent relationship. As a result, the mechanisms behind the reductive effects of dietary phytate on serum cholesterol still need to be investigated.

Several in vitro studies have been conducted on $\mathrm{InsP}_{6}$ 's antiviral potential on the human immunodeficiency virus (HIV). The compound was found to inhibit the cytopathic effect of this virus and the expression of the HIV-specific antigen (Kumar et al.,2010). In a T-cell line, InsP $\mathrm{P}_{6}$ was also shown to be able to suppress the replication of HIV-1 (Otake et al., 1999). Recently, Tateishi et al. (2014) found $\mathrm{InsP}_{6}$ to be able to tightly bind the matrix domain of the $\operatorname{Pr} 55^{\mathrm{Gag}}$ protein, which is a critical component for the assembly of the HIV-1 virus. Subsequently, these authors coupled $\mathrm{InsP}_{6}$ with diacylglycerol moieties to synthesize myo-phosphatidylinositol 2,3,4,5,6-pentakisphosphate derivatives. These derivatives were found to have an even stronger binding capacity with the Pr55 Gag protein's matrix domain, suggesting a potential molecular design for anti-HIV agents.

The effects of InsP $_{6}$ against mycotoxins have been investigated, with some results. InsP ${ }_{6}$ has been shown to impede the histopathological alterations caused by aflatoxin B1 in albino rats, which include heightened oxidative stress and decreased reproductive function (El-Saad and Mahmoud, 2009). In swine, $\mathrm{InsP}_{6}$ exhibited protective effects on the cytoplasmic membrane of intestinal cells when these cells were exposed to deoxynivalenol and fumonisin B1 (Silva et al.,2014b).

Because there is no unambiguous evidence that dietary InsPs can be absorbed, it is still unclear as to whether InsPs in foods can provide significant disease prevention. Yet, the growing number of findings pertaining to the physiological functions and potential benefits of InsPs promise that much remains to be learned about these compounds, and there is a need to separate and quantify InsPs in foods. While accurate and sensitive methods are becoming more available, the diversity of food and biomedical systems also require that modifications be investigated for each sample type.

\section{Methods of separation and quantification for InsPs}

Although InsP $_{6}$ was identified as far back as 1903 , the detection and quantification of InsPs have been of continuous interest for researchers to this day. These compounds do not possess a characteristic spectrophotometric absorbance maximum and are available only at relatively low concentrations. Currently, an optimal method for the complete separation and measurement of all InsPs with their isomers has yet to be developed.

\subsection{Non-specific methods}

Heubner and Stadler (1914) introduced a non-specific method for the determination of phytic acid in ground cereal powder (Rather, 1917). In this method, phytic acid is extracted with hydrochloric acid $(\mathrm{HCl})$ and then titrated with a ferric chloride solution in the presence of ammonium thiocyanate to form a pink-colored chromogen. The quantity of $\mathrm{Fe}^{3+}$ that reacts is used to calculate the phytic acid content. Because ferric phytate forms as a white precipitate, the exact end point of this titration is difficult to detect. Furthermore, the mole ratio between $\mathrm{Fe}^{3+}$ and $\mathrm{InsP}_{6}$ in the complex is inconsistent. Using the assumption that the total phosphorous content of the sample would originate from phytate, McCance and Widdowson (1935) later modified this method by quantifying the phosphorus content of the ferric phytate precipitate instead of $\mathrm{Fe}^{3+}$. A major disadvantage of assays that depend on ferric phytate is the overestimation of phytic acid in samples with high contents of inorganic phosphorus and/or non-InsPs organic phosphates, as these compounds can also precipitate with the ferric ion. Even today similar research continues: Burgos-Luján and Tong (2015) recently described a method based on the back-titration of ferric phytate with EDTA for the measurement of phytic acid in fluid food samples. McKie and McCleary (2016) also reported a modified colorimetric molybdenumblue assay to measure the amount of inorganic phosphate released from extracted phytic acid of foods and animal feeds as a result of dephosphorylation with phytase and alkaline phosphatasetreatment.

To eliminate inorganic phosphorus from samples, researchers have attempted to develop quantitative methods based on ionexchange interactions. Most notable is a method by Harland and Oberleas (1977), in which the supernatant from an $\mathrm{HCl}$ extraction of the sample is placed on an AG 1-X8 chloride form anion-exchange column. The column is rinsed with water and $0.05 \mathrm{M} \mathrm{NaCl}$ to elute inorganic phosphates. Organic phosphates trapped on the resin are then eluted with $0.7 \mathrm{M} \mathrm{NaCl}$. Assuming that phytates accounts for all forms of organic phosphates in the sample, an acid digestion of the final fraction followed by the measurement of inorganic phosphates via the Fiske-Subbarow colorimetric method can be used to infer the phytate content. In the Fiske-Subbarow assay, the sample is treated with ammonium molybdate to form phosphomolybdate, which can be reduced to molybdenum blue in the presence of a reductant, such as aminonaphthosulfonic acid (Goldenberg and Fernandez, 1966). The intensity of the bluecolored chromogen, with maximum absorbance at $\lambda=640 \mathrm{~nm}$, is directly correlated to the concentration of phosphate in the sample. In an improvement of this method, Ellis and Morris (1983) added EDTA and $\mathrm{NaOH}$ to prevent the binding of $\mathrm{InsP}_{6}$ to proteins and metal ions in the extraction. This version was later adopted as the official AOAC method (986.11) for determining phytate in foods (AOAC International,2005).

Due to the non-specificity of this chromatographic method, the InsP ${ }_{6}$ concentration can still be heavily overestimated in samples where InsP $\mathrm{P}_{1-5}$ make up more than $20 \%$ of the InsP content (Lehrfeld and Morris 1992). Additionally, sugar phosphates, phospholipids, nucleotides, and phosphate derivatives of thiamine also contribute to the organic phosphate levels in foods. Overestimation problems are of particular importance, because foods and diet patterns reported to have high phytic acid contents would often be associated with mineral deficiency concerns.

\subsection{Specific methods}

While working with soil, Smith and Clark (1952) were able to extract InsP $\mathrm{P}_{3-6}$ from hydrolyzed sodium phytate via anion-exchange chromatography, utilizing a weak-base exchange resin and stepwise elution with increasing $\mathrm{HCl}$ concentration (Cosgrove, 1963a). The content of each InsP was deduced via the phosphorus-inositol ratio in each collected fraction. Later, Cosgrove (1963b) demon- 
strated that utilizing the strong anion exchange resin AG 1 for this method allowed for separation of different $\mathrm{InsP}_{5}$ isomers. The author, however, did not perform a quantification of InsPs in food samples.

To achieve a shorter elution time, Tangendjaja et al. (1980) then applied high-performance liquid chromatography (HPLC), particularly reversed-phase chromatography, using a $\mu$ Bondapak C18 column and sodium acetate as mobile phase. Graf and Dintzis (1982) later improved this method by adding a purification step with the AG 1 resin after extraction. With both methods, however, the retention time of $\mathrm{InsP}_{6}$ was less than 2 min and other InsPs could not be identified. In a modification, Sandberg and Ahderinne (1986) used formic acid/methanol as the mobile phase and added tetrabutylammonium hydroxide as the ion-pair reagent, thus affording an increase in the retention time and differentiation between $\operatorname{InsP}_{3-6}$, although their stereoisomers were still indiscriminable.

Around this time, the application of gas chromatography (GC) in InsP analysis was also explored. Heathers et al. (1989) derivatized InsP fractions collected from HPLC separation into hexatrimethylsilyl derivatives for quantification by GC, and successfully applied this method to isomers of $\operatorname{InsP}_{1-3}$. The need for a derivatization process and the inability to measure $\mathrm{InsP}_{4-6}$ are considered drawbacks for this method.

Overall, HPLC is still the most common separation technique for InsPs due to its versatility. While ion-pair reversed-phase HPLC has been succesfully used to separate InsPs, anion-exchange HPLC has become more popular due to its ease of use. In recent decades, many different mobile phase gradients and anionexchangers for HPLC have been applied to separate InsPs down to their isomers. Nevertheless, it remains that $\mathrm{InsP}_{3-6}$ are better eluted with an acidic mobile phase while $\mathrm{InsP}_{1-2}$ prefer an alkaline mobile phase (Schlemmer et al., 2009). Good separation of all InsPs and their isomers is unlikely to be achieved in the same run, while time-effective separation of $\operatorname{InsP}_{1-6}$ in one run will sacrifice information on isomers. It should be noted that a high $\mathrm{pH}$ level may reduce the life time of a silica-based stationary phase; when an alkaline mobile phase is utilized, a polymer-based column is preferable. Therefore, there might be some limitations to the choice of column for the sensitive detection of InsP $_{1-2}$ by HPLC (Sjöberg et al., 2016).

Taking advantage of the exchange of $\mathrm{Fe}^{3+}$ from the ferric sulfosalicylic acid complex to phytate, Latta and Eskin (1980) developed a colorimetric detection method using a modified Wade reagent. Reaction with phytate in a sample extract would result in a loss in the absorbance at $\lambda=500 \mathrm{~nm}$ for this purple reagent. Rounds and Nielsen (1993) then modified this assay by replacing the AG 1 resin in the preceding method with another polystyrenebased strong anion-exchanger equipped on HPLC. Effluent from the analytical column was combined with a post-columnreagent of $0.015 \% \mathrm{FeCl}_{3} \cdot 6 \mathrm{H}_{2} \mathrm{O}(\mathrm{w} / \mathrm{v})$ plus $0.15 \%(\mathrm{w} / \mathrm{v})$ sulfosalicylic acid; this allowed for decrease absorbance readings at $\lambda=500 \mathrm{~nm}$ to be monitored as the eluting phosphates complexed with iron in the reagent. Using this approach, $\mathrm{InsP}_{2-6}$ could be separated within $30 \mathrm{~min}$. Recently, Agostinho et al. (2016) introduceda similar postcolumn detection method based on the inhibitory effect by $\mathrm{InsP}_{6}$ on the formation of the red complex between glyoxal bis(2-hydroxyaniline) and calcium ions in alkaline.

In 1988, another post-column dye-detection method was developed based on the exchange of yttrium ionfrom the $\mathrm{Y}^{3+}{ }_{-} 4-(2-$ pyridylazo)resorcinol complex to InsPs, which reduces the absorbance at $\lambda=546 \mathrm{~nm}$ of this colored complex (Mayr, 1988). In a modified method utilizing the same approach, Guse et al. (1993) were able to quantify $\mathrm{InsP}_{3-6}$ in cell extracts with high sensitivity: the detection limits were approximately $15 \mathrm{pmol}$ for $\mathrm{Ins}_{3}, 10 \mathrm{pmol}$ for
InsP $_{4}, 5$ pmol for InsP $\mathrm{P}_{5}$, and 1 to 3 pmol for InsP $\mathrm{P}_{6}$. Yet, this method requires great care to avoid contamination of the eluent with ions such as $\mathrm{Fe}^{3+}$ and $\mathrm{Zn}^{2+}$, as these ions can complex with both InsPs and 4-(2-pyridylazo)resorcinol.

Ligand exchange reactions between InsPs and fluorescent complexes have also been introduced, including the use of a ferric methylcalcein blue complex, copper(II) gelatin complex, and copper(II) 2,2'-bipyridine complex (Cao et al., 2011; Chen et al., 2007; Irth et al., 1990). Interestingly, $\operatorname{InsP}_{6}$ has been found to activate the oxidation of 1,1'-dipyridyl ketone hydrazone (DPKH) in the presence of $\mathrm{Cu}^{2+}$, resulting in an intense fluorescent product (March et al., 1999). The authors suggest that the copper(II)phytate complex may have heightened catalytic activity compared with $\mathrm{Cu}^{2+}$ alone on the reaction between DPKH and oxygen. This method is useful for the detection of phytic acid in foods and urine.

A method for on-line detection of InsPs has always been in demand. In qualitative studies on cells and tissue, a number of authors have chosen to radiolabel their samples with myo- $\left[{ }^{3} \mathrm{H}\right]$ inositol or $\left[{ }^{31} \mathrm{P} \mathrm{PO}_{4}{ }^{3-}\right.$. In working on several isomers of InsP $\mathrm{P}_{1-4}$, Taylor et al.(1990) coupled this technique with separation via HPLC for the quantitation of InsPs. They successfully recorded changes in the distribution of the analytes overtime, proposing a potential approach for the study of InsPs in biological processes, such as cellular signaling. Due to the lack of absolute concentration data, this method is considered unsuitable for many research purposes. Furthermore, it is laborious and less sensitive than some off-line analyses. Instead, several studies have investigated the application of chemically-suppressed conductivity and the researchers were able to separate different phosphorylated organic compounds, including InsPs, in both physiological and food samples (Smith and MacQuarrie, 1988; Talamondet al.,2000). Notable is the coupling of isotachophoresis and zone electrophoresis with contact conductivity, as demonstrated by Kvasnička et al. (2011).

When multiple InsPs are being identified or when matrix effects can cause the elution times of InsPs to deviate from those of standard compounds, reliance on retention time for detection in HPLC methods can also risk inaccurate interpretation. Nuclear magnetic resonance (NMR) spectroscopy, atomic emission spectroscopy (AES), and mass spectrometry (MS) are among detection techniques that can reduce this risk in susceptible samples. ${ }^{31} \mathrm{P}$ NMR spectroscopy is prized as a noninvasive and highly specific method for InsP determination. Because it can be applied on intact tissues and cell suspensions, it is especially suitable for the study of InsP metabolism, binding activities, and degradation (Heighton et al., 2008; Zhuang et al., 2010). Alternatively, some authors have used ${ }^{1} \mathrm{H}-\mathrm{NMR}$ to study the interactions between $\operatorname{Ins}_{6}$ and paramagnetic metal ions such as ferric and ferrous ions (Heighton et al., 2008). NMR can be used to identify and confirm stereoisomers that often coelute during chromatographic separation (Phillippy, 1989). The disadvantages of NMR, however, are that the technique is relatively insensitive, cost-prohibitive, and spectra can be very complex (Kemme et al., 1999; Schlemmer et al., 2009).

In 1996, a method using inductively coupled plasma (ICP) combined with AES for Ins $\mathrm{P}_{6}$ determination in urine was reported, but the sample treatment process is long, complicated, and requires a large amount of sample (Grases and Llobera, 1996). Later, a more efficient and sensitive method was developed, attaining a limit of detection of $64 \mu \mathrm{g} / \mathrm{L}$ and limit of quantification of $213 \mu \mathrm{g} / \mathrm{L}$ (Grases et al.,2004a). Although still less sensitive than ICP coupled with MS, this method is considered suitable for routine determination. A preliminary study by Amaro et al. (2004) suggested that coupling HPLC with ICP-AES can improve sensitivity.

Mass spectrometry (MS) and tandem mass spectrometry (MS/ MS) are powerful approaches to attain high sensitivity and can be 
coupled with HPLC, GC, and ICP for different purposes. ICP-MS is suitable for biomedical samples such as urine (Muñoz and Valiente, 2003). For food samples, the use of sector field ICP-MS has been investigated with initial success (Helfrich and Bettmer, 2004). GC-MS has also been applied for food and biological samples, such as rat organs, human plasma, urine and kidney stones (de Koning, 1994; March et al., 2001), but this method still requires a derivatization step of InsPs to trimethysilyl derivatives. HPLC-MS can achieve comparable results without calling for derivatization of the sample (Perelló et al.,2004). Further modification may even eliminate all together the need for a separate chromatographic extraction step preceding detection. Using negative mode electrospray ionization (ESI) with anion-exchange HPLC-MS/MS, Liu et al. (2009) were able to simultaneously separate and quantify InsP ${ }_{1-6}$ from various foods and cell samples, with sensitivity reaching as low as the pmol range and elution time of less than $30 \mathrm{~min}$. This can be considered one of the most efficient methods for measuring InsPs in samples without regard to stereoisomers. A similar method was later successfully applied for the qualitative detection of InsPs from environmental matrices, including soil, manure, and aquatic sediments (Sjöberg et al., 2016). Recently, Zhang et al. (2017) introduced a method coupling ion-pair chromatography with ESI/MS/MS that could detect InsP $\mathrm{P}_{1-6}$ within $15 \mathrm{~min}$ of sample injection and achieved very low limits of detection for InsP $_{1-5}$ (less than 1 pmol). Another notable method which utilized MS/MS was described by Shelor et al. (2015), in which hydroxide eluent ion chromatography was coupled with MS/MS. In addition to simultaneously detecting InsP $\mathrm{P}_{1-6}$, this method was able to fully separate several stereoisomers of Ins $\mathrm{P}_{2-6}$ in a 50min run. Unfortunately, the authors did not attempt to identify the structure of these isomers. An advantage of using MS/MS compared to ICP-MS is the potential of discriminating structural isomers based solely on mass spectrometry information. Utilizing positive-ion mode ESI with low-energy collisional-activated dissociation MS/MS, Hsu et al. (2003) were able to differentiate the stereoisomers of $\operatorname{InsP}_{1}$, Ins $\mathrm{P}_{2}$, and $\mathrm{InsP}_{3}$ in bovine brain extract. This method was unable to identify the stereoisomers of $\mathrm{InsP}_{4}$ and $\mathrm{InsP}_{5}$, however, and how it can be applied for the quantification of InsP $_{1-3}$ isomers still needs to be examined.

\section{Inositol phosphates in plant foods}

The distribution of InsPs in plant seeds varies greatly, with the major concentration sites being the bran, germ, and the cotyledon. For cereals, $\mathrm{InsP}_{6}$ has been found to occur mainly in the germ of corn, the aleurone of wheat, the bran of rice, and the germ and bran of pearl millets (O'Dell et al., 1972; Reddy et al., 1989). On the other hand, legumes deposit $\mathrm{InsP}_{6}$ throughout the cotyledon. Further structural characteristic of InsP depositions can be attained via toluidine blue staining, where these compounds would appear red-violet under an optical microscope. In almond meal and hazelnuts, for example, these depositions have been found to be small pockets densely surrounded by proteins, suggesting the storage location of InsPs in these foods (Andriotis et al., 2005; Dourado et al., 2004).

Existing data on the InsP $_{6}$ content of plant seeds have mainly reported only $\mathrm{InsP}_{6}$ and the values have shown strong variations, especially with tree nuts, where the highest $\mathrm{InsP}_{6}$ value is can be 6- to 10-fold higher than the lowest value in the range (see Table 1 and 2). Significant variations in cereal $\mathrm{Ins}_{6}$ content due to cultivar, location, crop year, and fertilization have been observed in some but not all studies (Barrier-Guillot et al., 1996;Hídvégi and
Lásztity, 2002;McCall et al., 1953; Nahapetian and Bassiri, 1976; Singh and Sedeh, 1979; Steiner et al., 2007).The contribution of InsPs phosphorus to total phosphorus content in plant seeds hasbeen found to vary widely, ranging from 30 to $95 \%$ in cereals and legumes, and 25 to $75 \%$ in tree nuts (Deshpande, 2002; Lolas et al., 1976; O'Dell et al., 1972; Reddy et al., 1989; Rodehutscord et al., 2016). Steiner et al. (2007) have identified a positive correlation between $\mathrm{InsP}_{6}$ phosphorus and total phosphorus content in some cereals and legumes, with the relationship stronger in legumes than in cereals.

It is important to note that drawing a general consensus on the occurrence of $\mathrm{InsP}_{6}$ in food products is difficult because not all studies utilized specific methods and some studies have estimated the $\mathrm{InsP}_{6}$ content by assuming that a certain percentage of the total phosphorus content comprises phytic acid, which disregards possible deviations due to cultivation and processing factors. Furthermore, it is unclear whether indirect assays measure $\mathrm{Ins}_{6}$ as phytic acid or its salt forms (phytate/phytin), which can vary in number and the type of mineral cation bound to the molecule. In light of the recent findings on the potential roles of different InsPs in human health, it has become important to accurately assess the InsPs levels in foods with specific methods.

Although information on the abundance of $\operatorname{InsP}_{1-5}$ in plant seeds is still limited, some differences among different plants have been identified. Stepwise dephosphorylation of $\mathrm{InsP}_{6}$ by phytases extracted from the bran of spelt, rye, barley, and oat have identified the products to be $\operatorname{Ins}(1,2,3,5,6) \mathrm{P}_{5}, \operatorname{Ins}(1,2,5,6) \mathrm{P}_{4}, \operatorname{Ins}(1,2,6)$ $\mathrm{P}_{3}$, Ins(1,2) $\mathrm{P}_{2}$, and Ins(2)P (Greiner and Alminger, 2001). With phytase from rice bran, dephosphorylation can result in the same products, as well as $\operatorname{Ins}(1,2,3,4,5) \mathrm{P}_{5}, \operatorname{Ins}(1,2,3,4) \mathrm{P}_{4}$, and $\operatorname{Ins}(1,2,3)$ $\mathrm{P}_{3}$ (Hayakawa et al., 1990). Similarly, by using phytase extracted from wheat, the major hydrolysis pathway of InsP ${ }_{6}$ would result the same products listed by Greiner and Alminger (2001), while a minor pathway may instead produce $\operatorname{Ins}(1,2,3,6) \mathrm{P}_{4}$ and $\operatorname{Ins}(1,2,3)$ $\mathrm{P}_{3}$ as $\mathrm{InsP}_{4}$ and $\mathrm{InsP}_{3}$ products (Nakano et al., 2000). Lim and Tate (1973) have shown that $\operatorname{Ins}(1,3,4,5,6) \mathrm{P}_{5}, \operatorname{Ins}(1,2,3,4,5) \mathrm{P}_{5}$, $\operatorname{Ins}(1,2,3,4,6) \mathrm{P}_{5}$, Ins $(1,2,3,4) \mathrm{P}_{4}$, and $\operatorname{Ins}(1) \mathrm{P}$ may also be produced in wheat, suggesting that multiple types of phytase may be present. This effect has been observed with phytases from lupine seeds, in which the phytase LP2 produces $\operatorname{Ins}(1,2,3,4,5) \mathrm{P}_{5}$ and $\operatorname{Ins}(1,2,3,4)$ $\mathrm{P}_{4}$ while the two phytases LP11 and LP12 produces Ins $(1,2,4,5,6)$ $\mathrm{P}_{5}$ and $\operatorname{Ins}(1,2,5,6) \mathrm{P}_{4}$. After generating these products, all three phytases would produce $\operatorname{Ins}(1,2,6) \mathrm{P}_{3}, \operatorname{Ins}(1,2) \mathrm{P}_{2}$, and $\operatorname{Ins}(2) \mathrm{P}$ (Greiner et al., 2002).

Interestingly, in surveying multiple genotypes of barley, oats, rye, maize, triticale, and wheat, Rodehutscord et al. (2016) found Ins $(1,2,4,5,6) \mathrm{P}_{5}$ to be present in all samples, whereas $\operatorname{Ins}(1,2,3,4,5)$ $\mathrm{P}_{5}$ was only in barley, rye, triticale and wheat samples, and Ins $(1,2,3,4,6) \mathrm{P}_{5}$ was only in rye, triticale, and wheat samples. $\operatorname{InsP}_{4}$ was not identified in any sample. The only $\mathrm{InsP}_{3}$ isomer detected was $\operatorname{Ins}(1,5,6) \mathrm{P}_{3}$, which was determined in selected genotypes of barley, maize, and rye. These findings are in agreement with previous results by Kasim et al. (1998), where $\mathrm{InsP}_{4}$ was not detected in the grains of barley, corn, oats, sorghum, and wheat. The only published value of $\mathrm{InsP}_{4}$ in cereal we have found was reported by Helfrich and Bettmer (2004) for corn (maize). We are also unaware of values pertaining to the levels of Ins $\mathrm{P}_{1}$ and $\mathrm{InsP}_{2}$ in grains. Over all, cereal grains appear to be quite different from legumes and tree nuts, in which lower InsPs, including $\operatorname{InsP}_{1-2}$, were usually detected (Table 3 ).

Soaking and/or boiling have been found to significantly decreased InsP ${ }_{3-6}$ in both legumes and grains (El Tinay et al., 1989; Karle and Beleia, 2001; Lestienne et al., 2005a; Morris and Hill, 1996). In these processes, InsPs are hypothesized to be hydrolyzed 
Table 1. Content of myo-inositol hexakisphosphate in the grain/seed of major cereals and legumes

\begin{tabular}{|c|c|c|}
\hline Sample & Taxonomic names & Ins $P_{6}$ content $(\mu \mathrm{mol} / \mathrm{g})^{*}$ \\
\hline \multicolumn{3}{|l|}{ Cereal } \\
\hline Barley & Hordeum vulgare L. & $5.7-18.9^{2,13,15,16,18,19,26,30}$ \\
\hline Maize & Zea mays L. & $3.3-19.5^{2,12,13,15-17,19,20,23,25,26,31}$ \\
\hline Millet & Pennisteum spp. & $3.6-16.5^{17,25,28,31}$ \\
\hline Oats & Avena sativa $\mathrm{L}$. & $6.3-21.5^{6,11,13,15,18,19,26,30}$ \\
\hline Rice & Oryza sativa L. & $4.7-16.4^{6,17,19,23,25}$ \\
\hline Rye & Secale cereale L. & $6.6-14.7^{16,19,26,30}$ \\
\hline Sorghum & Sorghum spp. & $5.5-19.8^{15-17,19,20,24,25,31,33}$ \\
\hline Triticale & x Triticosecale Wittm. & $3.5-15.2^{16,19,26,29,29}$ \\
\hline Wheat & Triticum spp. & $4.9-20.5^{1,13,15,6,18,19,22,23,26,30}$ \\
\hline \multicolumn{3}{|l|}{ Legume } \\
\hline Chickpeas & Cicer arietinum L. & $4.2-19.1^{3,8,19,21,27}$ \\
\hline Common beans & Phaseolus vulgaris $\mathrm{L}$. & \\
\hline Black beans & & $6.7-14.9^{5,21}$ \\
\hline Kidney beans & & $7.4-16.1^{5,4,9,21,31}$ \\
\hline Pinto beans & & $7.8-12.1^{5,21,27}$ \\
\hline Great Northern beans & & $12.7-13.1^{5,21}$ \\
\hline Navy beans & & $12.4-12.6^{5,21}$ \\
\hline White beans & & $7.4-25.8^{8,27}$ \\
\hline Cowpeas & Vigna unguiculata $\mathrm{L}$. & $4.4-13.9^{13,17,19-21,31}$ \\
\hline Lentils & Lens culinaris Medikus & $3.7-15.9^{3,12,19,21,27}$ \\
\hline Mung beans & Vigna radiata (L.) R. Wilczek & $3.6-5.9^{5,17}$ \\
\hline Peas & Pisum sativum L. & $6.5-20.2^{13,10,19,34}$ \\
\hline Peanuts & Arachis hypogaea $\mathrm{L}$. & $2.6-10.3^{7,19,31,32}$ \\
\hline Soybeans & Glycine max (L.) Merr. & $13.3-28.8^{8,13,14,17-20,31}$ \\
\hline
\end{tabular}

${ }^{*}$ InsP ${ }_{6}$ : myo-inositol hexakisphosphate. ${ }^{1}$ Barrier-Guillot et al. 1996; ${ }^{2}$ Blatny et al. 1995; ${ }^{3}$ Burbanoet et al. 1995; ${ }^{4}$ Carnovale et al. $1988 ;{ }^{5} \mathrm{Chen} 2004 ;{ }^{6} \mathrm{de}$ Koning $1994 ;{ }^{7}$ Dost and Karaca 2016; ${ }^{8} \mathrm{El}$ Tinay et al. 1989; ${ }^{9} \mathrm{Ferguson}$ et al. $1988 ;{ }^{10} \mathrm{Fredrikson}$ et al. 2001; ${ }^{11} \mathrm{Harland}$ and Oberleas $1986 ;{ }^{12} \mathrm{Helfrich}$ and Bettmer $2004 ;{ }^{13} \mathrm{Hídvégi} \mathrm{and} \mathrm{Lásztity} 2002 ;{ }^{14}$ Karkle and Beleia 2010; ${ }^{15}$ Kasim and Edwards 1998; ${ }^{16}$ Lehrfeld 1989; ${ }^{17}$ Lestienne et al. 2005a; ${ }^{18}$ Lolas et al. 1976; ${ }^{19}$ Lott et al. 2000; ${ }^{20}$ Marfo et al. 1990; ${ }^{21}$ Morris and Hill 1996; ${ }^{22}$ Nahapetian and Bassiri 1976; ${ }^{23} \mathrm{O}$ 'Dell et al. 1972; ${ }^{24}$ Radhakrishnan \& Sivaprasad 1980; ${ }^{25}$ Ravindran et al. 1994; ${ }^{26}$ Rodehutscord et al. 2016; ${ }^{27}$ Simonet et al. 2003; ${ }^{28}$ Simwemba et al. 1984;

${ }^{29}$ Singh and Sedeh 1979; ${ }^{30}$ Steiner et al. 2007; ${ }^{31}$ Talamond et al. 2000; ${ }^{32}$ Venkatachalam and Sathe 2006; ${ }^{33}$ Wang et al. $1959 ;{ }^{34} \mathrm{Zdunczyk}$ et al. 1997.

Table 2. Content of myo-inositol hexakisphosphate in major tree nuts

\begin{tabular}{|c|c|c|}
\hline Sample & Taxonomic names & Ins $P_{6}$ content $(\mu \mathrm{mol} / \mathrm{g})^{*}$ \\
\hline Almonds & Prunus dulcis [Mill.] D.A. Webb & $5.3-32.0^{1,2,4-10}$ \\
\hline English walnuts & Juglans regia $\mathrm{L}$. & $2.7-21.0^{1,2,3,5,8,10}$ \\
\hline Cashews & Anacardium occidentale L. & $2.3^{-29.8^{1,3,5,8,10}}$ \\
\hline Brazil nuts & Bertholletia excelsa Humb. \& Bonpl.: Lecythidaceae & $2.9-27.3^{3,8,10}$ \\
\hline Macadamias & Macadamia integrifolia Maiden \& Betche & $2.3-14.3^{1,3,5,10}$ \\
\hline Pistachios & Pistachia vera $\mathrm{L}$. & $3.0-43.0^{3,5,8,10}$ \\
\hline Pecans & Carya illinoinensis (Wangenh.) K. Koch. & $1.8-28.9^{3,5,10}$ \\
\hline Hazelnuts & Corylus avellana $\mathrm{L}$. & $2.2-35.5^{2,3,5-10}$ \\
\hline Pine nuts & Pinus L. & $3.0-11.9^{8,10}$ \\
\hline
\end{tabular}

${ }^{*}{ }_{\text {InsP }}$ : myo-inositol hexakisphosphate. ${ }^{1}$ Chen $2004 ;{ }^{2}$ Dost and Karaca 2016; ${ }^{3}$ Duong et al. 2017a; ${ }^{4}$ Duong et al. $2017 \mathrm{~b} ;{ }^{5} \mathrm{Harland}$ et al. $2004 ;{ }^{6} \mathrm{Helfrich}$ and Bettmer 2004; ${ }^{7}$ Liu et al. 2009; ${ }^{8}$ Lott et al. 2000; ${ }^{9}$ Simonet et al. 2003; ${ }^{10}$ Venkatachalam and Sathe 2006. 
Table 3. Lower inositol phosphate contents in selected plant seeds*

\begin{tabular}{|c|c|c|c|c|c|}
\hline \multirow{2}{*}{ Sample } & \multicolumn{5}{|c|}{ Lower inositol phosphate content ( $\mu \mathrm{mol} / \mathrm{g}$ ) } \\
\hline & $\operatorname{InsP}_{5}$ & $\operatorname{InsP}_{4}$ & InsP $P_{3}$ & InsP ${ }_{2}$ & $\operatorname{InsP}_{1}$ \\
\hline \multicolumn{6}{|l|}{ Cereals } \\
\hline Barley & N.d. $-0.8^{6,9}$ & N.d..$^{6,9}$ & N.d. $-2.9^{6,9}$ & - & - \\
\hline Maize & $0.3-2.5^{5,6,9}$ & N.d. $-0.7^{5,6,9}$ & $0.1-0.5^{9}$ & - & - \\
\hline Oat & $0.1-0.2^{9}$ & N.d. ${ }^{6,9}$ & N.d..$^{6,9}$ & - & - \\
\hline Rye & $0.2-0.4^{9}$ & N.d. ${ }^{9}$ & N.d. ${ }^{9}$ & - & - \\
\hline Sorghum & N.d. $-0.9^{6}$ & N.d. ${ }^{6}$ & N.d. ${ }^{6}$ & - & - \\
\hline Triticale & $0.2-0.4^{9}$ & N.d. ${ }^{9}$ & N.d. ${ }^{9}$ & - & - \\
\hline Wheat & N.d. $-0.5^{6.9}$ & N.d. ${ }^{6,9}$ & N.d. ${ }^{6,9}$ & - & - \\
\hline \multicolumn{6}{|l|}{ Legumes } \\
\hline Chickpeas & $-2.1^{1,8,10}$ & $0.04-0.6^{1,8,10}$ & $<0.005-0.6^{1,6,8}$ & $0.3^{10}$ & $0.1^{10}$ \\
\hline \multicolumn{6}{|l|}{ Common beans } \\
\hline Black beans & $0.5-3.2^{4,8}$ & $0.1^{8}$ & $<0.005^{8}$ & - & - \\
\hline Great Northern beans & $0.6-2.2^{4,8}$ & $0.2^{8}$ & $<0.005^{8}$ & - & - \\
\hline Navy beans & $0.6-1.8^{4,8}$ & $0.1^{8}$ & $<0.005^{8}$ & - & - \\
\hline Pink beans & $0.6^{4}$ & - & - & - & - \\
\hline Pinto beans & $0.3-3.1^{2,8,10}$ & $0.2-0.7^{8,10}$ & $<0.005-0.2^{8,10}$ & $0.2^{10}$ & $0.1^{10}$ \\
\hline Red kidney bean & $0.3-1.8^{2,8,10}$ & $0.2^{8}$ & $<0.005^{8}$ & - & - \\
\hline White beans & $3.0^{10}$ & $0.6^{10}$ & $0.2^{10}$ & $0.2^{10}$ & $0.2^{10}$ \\
\hline Cow peas & $2.5^{8}$ & $0.3^{8}$ & $0.01^{8}$ & - & - \\
\hline Lentils & $0.2-3.2^{1,5,8,10}$ & $0.1-0.8^{1,5,8,10}$ & $0.3-0.4^{1,8,10}$ & $0.3^{10}$ & $0.2^{10}$ \\
\hline Mung beans & $1.2^{2}$ & - & - & - & - \\
\hline \multicolumn{6}{|l|}{ Tree nuts } \\
\hline Almonds & $0.4-10.0^{2,4,5,7,10}$ & $0.4-8.5^{4,5,7,10}$ & $1.0-1.8^{4,7,10}$ & $0.7-3.8^{4,7,10}$ & $<0.002-1.5^{4,7,10}$ \\
\hline Cashews & $1.3-6.6^{2,3,5}$ & $0.3-1.2^{3,5}$ & $0.2-0.5^{3,5}$ & $0.07-0.2^{3,5}$ & $<0.002-0.2^{3,5}$ \\
\hline Hazelnuts & $0.4-1.2^{3,5,7,10}$ & $0.2-1.1^{3,7,10}$ & $0.01-0.5^{3,7,10}$ & $0.04-0.5^{3,7,10}$ & $0.003-0.3^{3,7,10}$ \\
\hline Macadamias & $0.6-1.2^{2,3}$ & $0.2^{3}$ & $0.02^{3}$ & $<0.002^{3}$ & $0.06^{3}$ \\
\hline Pecans & $0.3-0.5^{2,3}$ & $0.2^{3}$ & $0.08^{3}$ & $0.02^{3}$ & $0.04^{3}$ \\
\hline Pine nuts & $1.5^{10}$ & $1.1^{10}$ & $0.7^{10}$ & $0.9^{10}$ & $1.1^{10}$ \\
\hline English Walnuts & $0.8-1.6^{2,3}$ & $0.2^{3}$ & $0.02^{3}$ & $<0.002^{3}$ & $0.07^{3}$ \\
\hline
\end{tabular}

*InsP $\mathrm{P}_{1-5}$ are myo-inositol monophosphate, myo-inositol bisphosphate, myo-inositol trisphosphate, myo-inositol tetrakisphosphate, myo-inositol pentakisphosphate, respectively. N.d.: not detected and the author(s) did not specify the limit of detection: ${ }^{1}$ Burbano et al. $1995 ;{ }^{2}$ Chen et al. $2007 ;{ }^{3}$ Duong et al. $2017 \mathrm{a} ;{ }^{4}$ Duong et al. $2017 \mathrm{~b} ;{ }^{5} \mathrm{Helfrich}$ and Bettmer 2004; ${ }^{6}$ Kasim and Edwards 1998; ${ }^{7}$ Liu et al. 2009; ${ }^{8}$ Morris and Hill 1996; ${ }^{9}$ Rodehutscord et al. 2016; ${ }^{10}$ Simonet et al. 2003.

into inorganic phosphorus inside the grain. Phytases are expected to be quickly degraded upon heat application. Lestienne et al. (2005b) found the inorganic phosphorus level to increase in soaked soybeans, whereas the soaking fluid showed no similar change or any significant phytase activity. Karle and Beleia (2001) also demonstrated that heat application after soaking did not further decrease the $\mathrm{InsP}_{6}$ content of soybeans compared to when only soaking was employed. Marfo et al. (1990) observed a significant decrease in the InsP $\mathrm{P}_{6}$ level in several cereals and legumes after fermentation. This effect declined after 48 hours, which might be due to the inhibition of phytase activity by low the $\mathrm{pH}$ or increased abundance of inorganic phosphate. In processed foods containing cereals and legumes, the InsP levels can be affected by the processes mentioned above as well as the loss/removal of parts of the grain/seed and the inclusion of other ingredients, leading to great variation even within the same product type. For example, $\operatorname{InsP}_{6}$ has been found to range from $<0.008$ to $50 \mu \mathrm{mol} / \mathrm{g}$ in ready-to-eat wheat cereals and $<0.008$ to $16.1 \mu \mathrm{mol} / \mathrm{g}$ in wheat breads (Harland et al., 2004; Reddy et al., 1989).

\section{Conclusions}

InsPs and their abundances in plant foods have long been a con- 
cern for nutrient absorption, especially for populations that may be more susceptible for nutrient deficiencies, including children, vegetarians, and residents in developing countries. This review has summarized some of the nutrients most affected by InsPs, as well as several factors that may influence InsPs capabilities to inhibit the absorption of this nutrition in the gut. Additionally, InsP roles in normal mammal biological functions, the potential for disease prevention, and the possibility for absorption from food sources were discussed. In each of these areas of interest, it is evident that many questions are still unanswered and further research is needed to improve the state of knowledge. Thus, more research on rapid and sensitive analytical methods to determine InsPs in food and biological systems is warranted.

\section{References}

Agostinho, A.J., Oliveira, W.S., Anunciação, D.S., and Santos, J.C.C. (2016). Simple and sensitive spectrophotometric method for phytic acid determination in grains. Food Analysis Methods 9: 2087-2096.

Agte, V., Jahagirdar, M., and Chiplonkar, S. (2005). Apparent absorption of eight micronutrients and phytic acid from vegetarian meals in ileostomized human volunteers. Nutrition 21: 678-685.

Amaro, R., Escalona, A., and Murillo, M. (2004). HPLC with inductively coupled plasma optical emission spectrometric detection for the analysis of inositol phosphates. Journal of Chromatographic Science 42: 491-494.

Andriotis, V.M.E., Smith, S.B., and Ross, J.D. (2005). Phytic acid mobilization is an early response to chilling of the embryonic axes from dormant oilseed of hazel (Corylus avellana). Journal of Experimental Botany 56: 537-545.

Anekonda, T.S., Wadsworth, T.L., Sabin, R., Frahler, K., Harris, C., Petriko, B., Ralle, M., Woltjer, R., and and Quinn, J.F. (2011). Phytic acid as a potential treatment for Alzheimer's pathology: Evidence from animal and in vitro models. Journal of Alzheimer's Disease 23: 21-35.

AOAC International. (2005). AOAC Official Method 986.11. Phytate in foods, anion exchange method. In: Official Methods of Analysis of AOAC International, 18th Edition, p., AOAC International, Rockville, $M D$.

Barrier-Guillot, B., Casado, P., Maupetit, P., Jondreville, C., Gatel, F., and Larbier, M. (1996). Wheat phosphorus availability: 1-In vitrostudy; factors affecting endogenous phytasic activity and phytic phosphorus content. Journal of the Science of Food and Agriculture 70: 62-68.

Baten, A., Ullah, A., Tomazic, V.J., and Shamsuddin, A.M. (1989). Inositolphosphate-induced enhancement of natural killer cell activity correlates with tumor suppression. Carcinogenesis 10: 1595-1598.

Bhowmik, A., Ojha, D., Goswami, D., Das, R., Chandra, N.S., Chatterjee, T.K., Chakravarty, A., Chakravarty, S., and Chattopadhyay, D. (2017). Inositol hexaphosphoric acid (phytic acid), a nutraceuticals, attenuates iron-induced oxidative stress and alleviates liver injury in iron overloaded mice. Biomedicine \& Pharmacotherapy 87: 443-450.

Blatny, P., Kvasnicka, F., and Kenndler, E. (1995). Determination of Phytic Acid in Cereal Grains, Legumes, and Feeds by Capillary Isotachophoresis. Journal of Agricultural and Food Chemistry 43: 129-133.

Bohn, L., Meyer, A.S., and Rasmussen, S.K. (2008). Phytate: impact on environment and human nutrition. A challenge for molecular breeding. Journal of Zhejiang University Science B 9: 165-191.

Burbano, C., Muzquiz, M., Osagie, A., Ayet, G., and Cuadrado, C. (1995). Determination of phytate and lower inositol phosphates in Spanish legumes by HPLC methodology. Food Chemistry 52: 321-325.

Burgos-Luján, I., and Tong, A.Z. (2015). Determination of phytic acid in juices and milks by developing a quick complexometric-titration method. Food Analysis Methods 8: 1836-1841.

Cao, S., Dong, N., and Chen, J. (2011). Synchronous fluorescence determination of phytic acid in foodstuffs and urine based on replacement reaction. Phytochemical Analysis 22: 119-123.

Carnovale, E., Lugaro, E., and Lombardi-Boccia, G. (1988). Phytic acid in faba bean and pea: effect on protein availability. Cereal Chemistry 65: 114-117.
Champagne, E.T., Fisher, M.S., and Hinojosa, O. (1990). NMR and ESR studies of interactions among divalent cations, phytic acid, and $\mathrm{N}$-acetylamino acids. Journal of Inorganic Biochemistry 38: 199-215.

Chen, Q. (2004). Determination of phytic acid and inositol pentakisphosphates in foods by high-performance ion chromatography. Journal of Agricultural and Food Chemistry 52: 4604-4613.

Chen, Y., Chen, J., Ma, K., Cao, S., and Chen, X. (2007). Fluorimetric determination of phytic acid in urine based on replacement reaction. Analytica Chimica Acta 605: 185-191.

Conte, A., Pizá, P., García-Raja, A., Grases, F., Costa-Bauzá, A., and Prieto, R.M. (1999). Urinary lithogen risk test: usefulness in the evaluation of renal lithiasis treatment using crystallization inhibitors (citrate and phytate). Archivos Españoles de Urología 52: 305-310.

Cosgrove, D.J. (1963a). The chemical of soil organic phosphores. I. Inositol phosphates. Australian Journal of Soil Research 1: 203-214.

Cosgrove, D.J. (1963b). The isolation of myoinositol pentaphosphates from hydrolysates of phytic acid. Biochemical Journal 89: 172-175.

Costa-Bauzá, A., Isern, B., Perelló, J., Sanchis, P., and Grases, F. (2005). Factors affecting the regrowth of renal stones in vitro: A contribution to the understanding of renal stone development. Scandinavian Journal of Urology and Nephrology 39: 194-199.

Crea, P., de Robertis, A., de Stefano, C., and Sammartano, S. (2006). Speciation of phytate ion in aqueous solution. Sequestration of magnesium and calcium by phytate at different temperatures and ionic strengths, in $\mathrm{NaCl}_{\mathrm{aq}}$. Biophysical Chemistry 124: 18-26.

Crea, F., De Stefano, C., Milea, D., and Sammartano, S. (2008). Formation and stability of phytate complexes in solution. Coordination Chemistry Reviews 252: 1108-1120.

Curhan, G.C., Willett, W.C., Knight, E.L., and Stampfer, M.J. (2004). Dietary factors and the risk of incident kidney stones in younger women: Nurses' health study II. Archives of Internal Medicine 164: 885-891.

Davidsson, L., Galan, P., Kastenmayer, P., Cherouvrier, F., Juillerat, M.-A., Hercberg, S., and Hurrell, R.F. (1994). Iron bioavailability studied in infants: The influence of phytic acid and ascorbic acid in infant formulas based on soy isolate. Pediatric Research 36: 816-822.

de Koning, A.J. (1994). Determination of myo-inositol and phytic acid by gas chromatography using scyllitol as internal standard. The Analyst 119: 1319-1323.

Deliliers, G.L., Servida, F., Fracchiolla, N.S., Ricci, C., Borsotti, C., Colombo, G., and Soligo, D. (2002). Effect of inositol hexaphosphate (IP $\left.{ }_{6}\right)$ on human normal and leukaemic haematopoietic cells. British Journal of Haematology 117: 577-587.

Denstadli, V., Skrede, A., Krogdahl, Å., Sahlstrøm, S., and Storebakken, T. (2006). Feed intake, growth, feed conversion, digestibility, enzyme activities and intestinal structure in Atlantic salmon (Salmo salar L.) fed graded levels of phytic acid. Aquaculture 256: 365-376.

Deshpande, S.S. (2002). Chapter 10: Toxicants and antinutrients in plant foods. In:Handbook of Food Toxicology, pp. 321-386. CRC Press, Florida.

Dost, K., and Karaca, G. (2016). Evaluation of phytic acid content of some tea and nut products by reverse-phase high performance liquid chromatography/visible detector. Food Analytical Methods 9: 1391-1397.

Dourado, F., Barros, A., Mota, M., Coimbra, M.A., and Gama, F.M. (2004). Anatomy and cell wall polysaccharides of almond (Prunus dulcis D.A. Webb) seeds. Journal of Agricultural and Food Chemistry 52: 13641370 .

Duong, Q.H., Clark, K.D., Lapsley, K.G., and Pegg, R.B. (2017a). Determination of myo-inositol phosphates in tree nuts and grain fractions by HPLC-ESI-MS. Journal of Food Composition and Analysis 59: 74-82.

Duong, Q.H., Clark, K.D., Lapsley, K.G., and Pegg, R.B. (2017b). Quantification of inositol phosphates in almond meal and almond brown skins by HPLC/ESI/MS. Food Chemistry 229: 84-92.

Ellis, R., and Morris, E.R. (1983). Improved ion-exchange phytate method. Cereal Chemistry 60: 121-124.

El-Saad, A.S.A., and Mahmoud, H.M. (2009). Phytic acid exposure alters aflatoxin B1-induced reproductive and oxidative toxicity in albino rats (Rattus norvegicus). Evidence-Based Complementary and Alternative Medicine 6: 331-341.

El Tinay, A.H., Mahgoub, S.O., Mohamed, B.E., and Hamad, M.A. (1989). Proximate composition and mineral and phytate contents of legumes grown in Sudan. Journal of Food Composition and Analysis 2: 69-78. 
Evans, D.F., Pye, G., Bramley, R., Clark, A.G., Dyson, T.J., and Hardcastle, J.D. (1988). Measurement of gastrointestinal pH profiles in normal ambulant human subjects. Gut 29: 1035-1041.

Ferguson, E.L., Gibson, R.S., Thompson, L.U., Ounpuu, S., and Berry, M. (1988). Phytate, zinc, and calcium contents of 30 East African foods and their calculated phytate:Zn, Ca:phytate, and [Ca][phytate]/[Zn] molar ratios. Journal of Food Composition and Analysis 1: 316-325.

Forbes, R.M., Parker, H.M., and Erdman, J.W. (1984). Effects of dietary phytate, calcium and magnesium levels on zinc bioavailability to rats. Journal of Nutrition 114: 1421-1425.

Fredlund, K., Isaksson, M., Rossander-Hulthén, L., Almgren, A., and Sandberg, A.-S. (2006). Absorption of zinc and retention of calcium: Dosedependent inhibition by phytate. Journal of Trace Elements in Medicine and Biology 20: 49-57.

Fredrikson, M., Alminger, M.L., Carlsson, N.-G., and Sandberg, A.-S. (2001). Phytate content and phytate degradation by endogenous phytase in pea (Pisum sativum). Journal of the Science of Food and Agriculture 81: 1139-1144.

Gemede, H.F. (2014). Potential health benefits and adverse effects associated with phytate in foods. Food Science and Quality Management 27: 45-54.

Goldenberg, H., and Fernandez, A. (1966). Simplified method for the estimation of inorganic phosphorus in body fluids. Clinical Chemistry 12: 871-882.

Graf, E., and Dintzis, F.R. (1982). High-performance liquid chromatographic method for the determination of phytate. Analytical Biochemistry 119: 413-417.

Grases, F., Costa-Bauza, A., Perelló, J., Isern, B., Vucenik, I., Valiente, M., Muñoz, J.A., and and Prieto, R.M. (2006). Influence of concomitant food intake on the excretion of orally administered myo-inositol hexaphosphate in humans. Journal of Medicinal Food 9: 72-76.

Grases, F., García-Ferragut, L., and Costa-Bauzá, A. (1996). Study of the early stages of renal stone formation: experimental model using urothelium of pig urinary bladder. Urological Research 24: 305-311.

Grases, F., and Llobera, A. (1996). Determination of phytic acid in urine by ICP atomic emission spectrometry. Analytical Letters 29: 1193-1199.

Grases, F., March, J.G., Prieto, R.M., Simonet, B.M., Costa-Bauzá, A., GarcíaRaja, A., and Conte, A. (2000). Urinary phytate in calcium oxalate stone formers and healthy people. Dietary effects on phytate excretion. Scandinavian Journal of Urology and Nephrology 34: 162-164.

Grases, F., Perelló, J., Isern, B., and Prieto, R.M. (2004a). Determination of myo-inositol hexakisphosphate (phytate) in urine by inductively coupled plasma atomic emission spectrometry. Analytica Chimica Acta 510: 41-43.

Grases, F., Perelló, J., Prieto, R.M., Simonet, B.M., and Torres, J.J. (2004b). Dietary myo-inositol hexaphosphate prevents dystrophic calcifications in soft tissues: a pilot study in Wistar rats. Life Sciences 75: 11-19.

Grases, F., Perelló, J., Sanchis, P., Isern, B., Prieto, R.M., Costa-Bauzá, A., Santiago, C., Ferragut, M.L., and and Frontera, G. (2009). Anticalculus effect of a triclosan mouthwash containing phytate: a double-blind, randomized, three-period crossover trial. Journal of Periodontal Research 44: 616-621.

Grases, F., Santiago, C., Simonet, B.M., and Costa-Bauzá, A. (2003). Sialolithiasis: mechanism of calculi formation and etiologic factors. Clinica Chimica Acta 334: 131-136.

Grases, F., Simonet, B.M., Vucenik, I., Perelló, J., Prieto, R.M., and Shamsuddin, A.M. (2002). Effects of exogenous inositol hexakisphosphate $\left(\operatorname{Ins}_{6}\right)$ on the levels of $\operatorname{InsP}_{6}$ and of inositol trisphosphate $\left(\operatorname{InsP}_{3}\right)$ in malignant cells, tissues and biological fluids. Life Sciences 71: 15351546.

Grases, F., Simonet, B.M., Vucenik, I., Prieto, R.M., Costa-Bauzá, A., March, J.G., and Shamsuddin, A.M. (2001). Absorption and excretion of orally administered inositol hexaphosphate (IP $\mathbb{P}_{6}$ or phytate) in humans. BioFactors 15: 53-61.

Greiner, R., and Alminger, M.L. (2001). Stereospecificity of myo-inositol hexakisphosphate dephosphorylation by phytate-degrading enzymes of cereals. Journal of Food Biochemistry 25: 229-248.

Greiner, R., Alminger, M.L., Carlsson, N.-G., Muzquiz, M., Burbano, C., Cuadrado, C., Mercedes, M.P., and Goyoaga, C. (2002). Pathway of dephosphorylation of myo-inositol hexakisphosphate by phytases of legume seeds. Journal of Agricultural and Food Chemistry 50: 6865-6870.

Gu, M., Raina, K., Agarwal, C., and Agarwal, R. (2010). Inositol hexaphosphate downregulates both constitutive and ligand-induced mitogenic and cell survival signaling, and causes caspase-mediated apoptotic death of human prostate carcinoma PC-3 cells. Molecular Carcinogenesi 49: 1-12.

Guse, A.H., Greiner, E., Emmrich, F., and Brand, K. (1993). Mass changes of inositol 1,3,4,5,6-pentakisphosphate and inositol hexakisphosphate during cell cycle progression in rat thymocytes. The Journal of Biological Chemistry 268: 7129-7133.

Hallberg, L., Rossander, L., and Skånberg, A. (1987). Phytates and the inhibitory effect of bran on iron absorption in man. The American Journal of Clinical Nutrition 45: 988-996.

Harland, B.F., and Oberleas, D. (1977). A modified method for phytate analysis using an ion-exchange procedure: Application to textured vegetable proteins. Cereal Chemistry 4: 827-832.

Harland, B.F., and Oberleas, D. (1986). Anion-exchange method for determination of phytate in foods: collaborative study. Journal of the Association of Official Analytical Chemists 69: 667-670.

Harland, B.F., Smikle-Williams, S., and Oberleas, D. (2004). High performance liquid chromatography analysis of phytate (IP6) in selected foods. Journal of Food Composition and Analysis 17: 227-233.

Hayakawa, T., Suzuki, K., Miura, H., Ohno, T., and Igaue, I. (1990). Myoinositol polyphosphate intermediates in the dephosphorylation of phytic acid by acid phosphatase with phytase activity from rice bran. Agricultural and Biological Chemistry 54: 279-286.

Heathers, G.P., Juehne, T., Rubin, L.J., Corr, P.B., and Evers, A.S. (1989). Anion exchange chromatographic separation of inositol phosphates and their quantification by gas chromatography. Analytical Biochemistry 176: 109-116.

Heighton, L., Schmidt, W.F., and Siefert, R.L. (2008). Kinetic and equilibrium constants of phytic acid and ferric and ferrous phytate derived from nuclear magnetic resonance spectroscopy. Journal of Agricultural and Food Chemistry 56: 9543-9547.

Helfrich, A., and Bettmer, J. (2004). Determination of phytic acid and its degradation products by ion-pair chromatography (IPC) coupled to inductively coupled plasma-sector field-mass spectrometry (ICP-SFMS). Journal of Analytical Atomic Spectrometry 19: 1330-1334.

Heubner, W., and Stadler, H. (1914). Über eine Titrationsmethode zur Bestimmung des Phytins. Biochemische Zeitschrift 64: 422-437.

Hídvégi, M., and Lásztity, R. (2002). Phytic acid content of cereals and legumes and interaction with proteins. Periodica Polytechnica Chemical Engineering 46: 59-64.

House, W.A., and Welch, R.M. (1987). Bioavailability to rats of iron in six varieties of wheat grain intrinsically labeled with radioiron. Journal of Nutrition 117: 476-480.

Hsu, F., Turk, J., and Gross, M.L. (2003). Structural distinction among inositol phosphate isomers using high-energy and low-energy collisionalactivated dissociation tandem mass spectrometry with electrospray ionization. Journal of Mass Spectrometry 38: 447-457.

lemma, F., Cirillo, G., Puoci, F., Trombino, S., Castiglione, M., and Picci, N. (2007). Iron(III) chelation and antioxidant properties of myo-inositol phosphorylated polymeric microspheres. Journal of Pharmacy and Pharmacology 59: 597-601.

International Zinc Nutrition Consultative Group (IZiNCG), Brown, K.H., Rivera, J.A., Bhutta, Z., Gibson, R.S., King, J.C., Lönnerdal, B., Ruel, M.T., Sandtröm, B., Wasantwisut, E., and Hotz, C. (2004). International Zinc Nutrition Consultative Group (IZiNCG) technical document \#1. Assessment of the risk of zinc deficiency in populations and options for its control. Food Nutrition Bulletin 25: S99-203.

Iqbal, T.H., Lewis, K.O., and Cooper, B.T. (1994). Phytase activity in the human and rat small intestine. Gut 35: 1233-1236.

Irth, H., Lamoree, M., de Jong, G.J., Brinkman, U.A.Th., Frei, R.W., Kornfeldt, R.A., and Persson, L. (1990). Determination of D-myo-1,2,6 inositol trisphosphate by ion-pair reversed-phase liquid chromatography with post-column ligand exchange and fluorescence detection. Journal of Chromatography A 499: 617-625.

Irvine, R.F., and Schell, M.J. (2001). Back in the water: The return of the inositol phosphates. Nature Reviews Molecular Cell Biology 2: 327-338.

Jariwalla, R.J., Sabin, R., Lawson, S., and Herman, Z.S. (1990). Lowering 
of serum cholesterol and triglycerides and modulation by dietary phytates. The Journal of Applied Nutrition 42: 18-28.

Joung, H., Jeun, B.Y., Li, S.J., Kim, J., Woodhouse, L.R., King, J.C., Welch, R.M., and Paik, H.Y. (2007). Fecal phytate excretion varies with dietary phytate and age in women. Journal of the American College of Nutrition 26: 295-302.

Karkle, E.N.L., and Beleia, A. (2010). Effect of soaking and cooking on phytate concentration, minerals, and texture of food-type soybeans. Food Science and Technology (Campinas) 30: 1056-1060.

Kasim, A.B., and Edwards, H.M. (1998). The analysis for inositol phosphate forms in feed ingredients. Journal of the Science of Food and Agriculture 76: 1-9.

Kazimoglu, K., Bozkurt, A.K., Suzer, O., Konukoglu, D., Koksal, C., Kurdal, T., and Turhan, M.S. (2004). The role of antioxidant supplementation in cardiac transplantation: An experimental study in rats. Transplantation Proceedings 36: 2939-2943.

Kemme, P.A., Lommen, A., De Jonge, L.H., Van der Klis, J.D., Jongbloed, A.W., Mroz, Z., and Beynen, A.C. (1999). Quantification of inositol phosphates using ${ }^{31} \mathrm{P}$ nuclear magnetic resonance spectroscopy in animal nutrition. Journal of Agricultural and Food Chemistry 47: 5116-5121.

Khan, A., and Ghosh, K. (2013). Phytic acid-induced inhibition of digestive protease and $\alpha$-amylase in three Indian major carps: An in vitro study. Journal of the World Aquaculture Society 44: 853-859.

Kim, S.M., Rico, C.W., Lee, S.C., and Kang, M.Y. (2010). Modulatory effect of rice bran and phytic acid on glucose metabolism in high fat-fed C57BL/6N mice. Journal of Clinical Biochemistry and Nutrition 47: $12-17$.

Klevay, L.M. (1975). Coronary heart disease: The zinc/copper hypothesis. The American Journal of Clinical Nutrition 28: 764-77.

Kong, F., and Singh, R.P. (2008). Disintegration of solid foods in human stomach. Journal of Food Science 73: R67-R80.

Konietzny, U., Jany, K.-D., and Greiner, R. (2006). Phytate - An undesirable constituent of plant-based foods? Journal für Ernahrungsmedizin 8: $18-28$.

Kornegay, E.T. (2000). Digestion of phosphorus and other nutrients: the role of phytases and factors influencing their activity. In:Enzymes in farm animal nutrition, pp. 237-271. Bedford, M.R., Partridge, G.G., Eds., CABI, Oxford.

Kumar, M.S., Reddy, B.S., Babu, S.K., Bhilegaonkar, P.M., Shirwaikar, A., and Unnikrishnan, M.K. (2004). Antiinflammatory and antiulcer activities of phytic acid in rats. Indian Journal of Experimental Biology 42: 179-185.

Kumar, V., Sinha, A.K., Makkar, H.P.S., and Becker, K. (2010). Dietary roles of phytate and phytase in human nutrition: A review. Food Chemistry 120: 945-959.

Kvasnička, F., Čopíková, J., Ševčík, R., Václavíková, E., Synytsya, A., Vaculová, K., and Voldřich, M. (2011). Determination of phytic acid and inositolphosphates in barley. Electrophoresis 32: 1090-1093.

Larsson, O., Sjöholm, Å., Carlqvist, H., Michell, R.H., Bertorello, A., Nilsson, T., Honkanen, R.E., Mayr, G.W., Zwiller, J., and Berggren, P. (1997). Inhibition of phosphatases and increased $\mathrm{Ca}^{2+}$ channel activity by inositol hexakisphosphate. Science 278: 471-474.

Latta, M., and Eskin, M. (1980). A simple and rapid colorimetric method for phytate determination. Journal of Agricultural and Food Chemistry 28: 1313-1315.

Lehrfeld, J. (1989). High-performance liquid chromatography analysis of phytic acid on a $\mathrm{pH}$-stable, macroporous polymer column. Cereal Chemistry 66: 510-515.

Lehrfeld, J., and Morris, E.R. (1992). Overestimation of phytic acid in foods by the AOAC anion-exchange method. Journal of Agricultural and Food Chemistry 40: 2208-2210.

Lestienne, I., Icard-Vernière, C., Mouquet, C., Picq, C., and Trèche, S. (2005a). Effects of soaking whole cereal and legume seeds on iron, zinc and phytate contents. Food Chemistry 89: 421-425.

Lestienne, I., Mouquet-Rivier, C., Icard-Vernière, C., Rochette, I., and Trèche, S. (2005b). The effects of soaking of whole, dehulled and ground millet and soybean seeds on phytate degradation and Phy/ $\mathrm{Fe}$ and Phy/Zn molar ratios. International Journal of Food Science \& Technology 40: 391-399.

Letcher, A.J., Schell, M.J., and Irvine, R.F. (2008). Do mammals make all their own inositol hexakisphosphate? The Biochemical Journal 412: 263-270.

Levrat-Verny, M., Coudray, C., Bellanger, J., Lopez, H.W., Demigné, C., Rayssiguier, Y., and Rémésy, C. (1999). Wholewheat flour ensures higher mineral absorption and bioavailability than white wheat flour in rats. British Journal of Nutrition 82: 17-21.

Lim, P.E., and Tate, M.E. (1973). The phytases. II. Properties of phytase fractions F1 and F2 from wheat bran and the myo-inositol phosphates produced by fraction F2. Biochimica et Biophysica Acta (BBA) - Enzymology 302: 316-328.

Liu, N., Ru, Y., Wang, J., and Xu, T. (2010). Effect of dietary sodium phytate and microbial phytase on the lipase activity and lipid metabolism of broiler chickens. British Journal of Nutrition 103: 862-868.

Liu, X., Villalta, P.W., and Sturla, S.J. (2009). Simultaneous determination of inositol and inositol phosphates in complex biological matrices: quantitative ion-exchange chromatography/tandem mass spectrometry. Rapid Communications in Mass Spectrometry 23: 705-712.

Lolas, G.M., Palamidis, N., and Markakis, P. (1976). The phytic acid-total phosphorus relationship in barley, oats, soybeans and wheat. Cereal Chemistry 53: 867-871.

Lönnerdal, B., Sandberg, A.-S., Sandström, B., and Kunz, C. (1989). Inhibitory effects of phytic acid and other inositol phosphates on zinc and calcium absorption in suckling rats. Journal of Nutrition 119: 211214.

Lopez, H.W., Coudray, C., Bellanger, J., Younes, H., Demigné, C., and Rémésy, C. (1998). Intestinal fermentation lessens the inhibitory effects of phytic acid on mineral utilization in rats. Journal of Nutrition 128 : 1192-1198.

Lopez, H.W., Leenhardt, F., Coudray, C., and andRémésy, C. (2002). Minerals and phytic acid interactions: is it a real problem for human nutrition? International Journal of Food Science and Technology 37: 727-739.

López-González, A.A., Grases, F., Roca, P., Mari, B., Vicente-Herrero, M.T., and Costa-Bauzá, A. (2008). Phytate (myo-inositol hexaphosphate) and risk factors for osteoporosis. Journal of Medicinal Food 11: 747-752.

Loss, O., Wu, C.T., Riccio, A., and Saiardi, A. (2013). Modulation of inositol polyphosphate levels regulates neuronal differentiation. Molecular Biology of the Cell 24: 2981-2989.

Lott, J.N.A., Ockenden, I., Raboy, V., and Batten, G.D. (2000). Phytic acid and phosphorus in crop seeds and fruits: a global estimate. Seed Science Research 10: 11-33.

Lückhoff, A., and Clapham, D.E. (1992). Inositol 1,3,4,5-tetrakisphosphate activates an endothelial $\mathrm{Ca}^{2+}$-permeable channel. Nature 355: 356358.

Majerus, P.W., Zou, J., Marjanovic, J., Kisseleva, M.V., and Wilson, M.P. (2008). The role of inositol signaling in the control of apoptosis. Advances in Enzyme Regulation 48: 10-17.

March, J.G., Simonet, B.M., and Grases, F. (1999). Fluorimetric determination of phytic acid based on the activation of the oxidation of 2,2'-dipyridyl ketone hydrazone catalysed by $\mathrm{Cu}(\mathrm{II})$. The Analyst 124 : 897-900.

March, J.G., Simonet, B.M., and Grases, F. (2001). Determination of phytic acid by gas chromatography-mass spectroscopy: application to biological samples. Journal of Chromatography B 757: 247-255.

Marfo, E.K., Simpson, B.K., Idowu, J.S., and Oke, O.L. (1990). Effect of local food processing on phytate levels in cassava, cocoyam, yam, maize, sorghum, rice, cowpea, and soybean. Journal of Agricultural and Food Chemistry 38: 1580-1585.

Mayr, G.W. (1988). A novel metal-dye detection system permits picomolar-range h.p.l.c. analysis of inositol polyphosphates from non-radioactively labelled cell or tissue specimens. Biochemical Journal 254: 585-591.

McCall, E.R., Jurgens, J.F., Hoffpauir, C.L., Pons, W.A., Stark, S.M., Cucullu, A.F., Heinzelman, D.C., Cirino, V.O., and Murray, M.D. (1953). Composition of rice, influence of variety and environment on physical and chemical composition. Journal of Agricultural and Food Chemistry 1: 988-993.

McCance, R.A., and Widdowson, E.M. (1935). Phytin in human nutrition Biochemical Journal 29: 2694-2699.

McKie, V.A., and McCleary, B.V. (2016). A novel and rapid colorimetric 
method for measuring total phosphorus and phytic acid in foods and animal feeds. Journal of AOAC International 99: 738-743.

Miyazawa, E., Iwabuchi, A., and Yoshida, T. (1996). Phytate breakdown and apparent absorption of phosphorus, calcium and magnesium in germfree and conventionalized rats. Nutrition Research 16: 603-613.

Monserrate, J.P., and York, J.D. (2010). Inositol phosphate synthesis and the nuclear processes they affect. Current Opinion in Cell Biology 22: 365-373.

Morris, E.R., and Hill, A.D. (1996). Inositol Phosphate Content of Selected Dry Beans, Peas, and Lentils, Raw and Cooked. Journal of Food Composition and Analysis 9: 2-12.

Muñoz, J.A., and Valiente, M. (2003). Determination of phytic acid in urine by inductively coupled plasma mass spectrometry. Analytical Chemistry 75: 6374-6378.

Nahapetian, A., and Bassiri, A. (1976). Variations in concentrations and interrelations of phytate, phosphorus, magnesium, calcium, zinc, and iron in wheat varieties during two years. Journal of Agricultural and Food Chemistry 24: 947-950.

Nakano, T., Joh, T., Narita, K., and Hayakawa, T. (2000). The pathway of dephosphorylation of myo-inositol hexakisphosphate by phytases from wheat bran of Triticum aestivum L. cv. Nourin \#61. Bioscience, Biotechnology, and Biochemistry 64: 995-1003.

Nassim, J.R., and Higgins, B.A. (1965). Control of idiopathic hypercalciuria. British Medical Journal 1: 675-681.

Norazalina, S., Norhaizan, M.E., Hairuszah, I., and Norashareena, M.S. (2010). Anticarcinogenic efficacy of phytic acid extracted from rice bran on azoxymethane-induced colon carcinogenesis in rats. Experimental and Toxicologic Pathology 62: 259-268.

O'Dell, B.L., de Boland, A.R., and Koirtyohann, S.R. (1972). Distribution of phytate and nutritionally important elements among the morphological components of cereal grains. Journal of Agricultural and Food Chemistry 20: 718-723.

Onomi, S., Okazaki, Y., and Katayama, Y. (2004). Effect of dietary level of phytic acid on hepatic and serum lipid status in rats fed a high-sucrose diet. Bioscience, Biotechnology, and Biochemistry 68: 1379-1381.

Onyango, E.J., Asern, E.K., and Adeola, O. (2008). Phytic acid increases mu$\mathrm{cin}$ and endogenous amino acid losses from the gastrointestinal tract of chickens. British Journal of Nutrition 101: 836-842.

Otake, T., Mori, H., Morimoto, M., Miyano, K., Ueba, M., Oishi, I., Kunita, M., and Kurimura, T. (1999). Anti-HIV-1 activity of myo-inositol hexaphosphoric acid (IP6) and myo-inositol hexasulfate (IS6). Anticancer Research 19: 3723-3726.

Otto, J.C., Kelly, P., Chiou, S-T., and York, J.D. (2007). Alterations in an inositol phosphate code through synergistic activation of a $\mathrm{G}$ protein and inositol phosphate kinases. Proceedings of the National Academy of Sciences of the United States of America 104: 15653-15658.

Park, H.-R., Ahn, H.-J., Kim, J.-H., Yook, H.-S., Kim, S., Lee, C.-H., and Byun, M.-W. (2004). Effects of irradiated phytic acid on antioxidation and color stability in meat models. Journal of Agricultural and Food Chemistry 52: 2572-2576.

Perelló, J., Isern, B., Muñoz, J.A., Valiente, M., and Grases, F. (2004). Determination of phytate in urine by high-performance liquid chromatography-mass spectrometry. Chromatographia 60: 265-268.

Persson, H., Tuerk, M., Nyman, M., and Sandberg, A.-S. (1998). Binding of $\mathrm{Cu}^{2+}, \mathrm{Zn}^{2+}$, and $\mathrm{Cd}^{2+}$ to inositol tri-, tetra-, penta-, and hexaphosphates. Journal of Agricultural and Food Chemistry 46: 3194-3200.

Phillippy, B.Q. (1989). Identification by two-dimensional NMR of myo-inositol tris- and tetrakis (phosphates) formed from phytic acid by wheat phytase. Journal of Agricultural and Food Chemistry 37: 1261-1265.

Phillippy, B.Q., and Graf, E. (1997). Antioxidant functions of inositol 1,2,3-trisphosphate and inositol 1,2,3,6-tetrakisphosphate. Free Radical Biology \& Medicine 22: 939-946.

Radhakrishnan, M.R., and Sivaprasad, J. (1980). Tannin content of sorghum varieties and their role in iron bioavailability. Journal of Agricultural and Food Chemistry 28: 55-57.

Raina, K., Ravichandran, K., Rajamanickam, S., Huber, K.M., Serkova, N.J., and Agarwal, R. (2013). Inositol hexaphosphate inhibits tumor growth, vascularity, and metabolism in TRAMP mice: A multiparametric magnetic resonance study. Cancer Prevention Research 6: 40-50.

Rao, P.S., Liu, X., Das, D.K., Weinstein, G.S., and Tyras, D.H. (1991). Pro- tection of ischemic heart from reperfusion injury by myo-inositol hexaphosphate, a natural antioxidant. The Annals of Thoracic Surgery 52: 908-912.

Rather, J.B. (1917). The determination of phytin phosphorus in plant products. Journal of the American Chemical Society 39: 2506-2515.

Ravindran, V., Ravindran, G., and Sivalogan, S. (1994). Total and phytate phosphorus contents of various foods and feedstuffs of plant origin. Food Chemistry 50: 133-136.

Reddy, M.B., Hurrell, R.F., Juillerat, M.A., and Cook, J.D. (1996). The influence of different protein sources on phytate inhibition of nonhemeiron absorption in humans. The American Journal of Clinical Nutrition 63: 203-207.

Reddy, N.R. Píeon, M.D., Sathe, S.K., and Salunkhe, D.K. (1989). Chapter 6: Occurrence, distribution, content, and dietary intake of phytate. In:Phytates in cereals and legumes, pp. 39-56. CRC Press, Florida.

Rimbach, G., and Pallauf, J. (1998). Phytic acid inhibits free radical formation in vitro but does not affect liver oxidant or antioxidant status in growing rats. Journal of Nutrition 128: 1950-1955.

Rodehutscord, M., Rückert, C., Maurer, H.P., Schenkel, H., Schipprack, W., Knudsen, K.E.B., Schollengerger, M., Laux, M., Eklund, M., Sieger, W., and Mosenthin, R. (2016). Variation in chemical composition and physical characteristics of cereal grains from different genotypes. Archives of Animal Nutrition 70: 87-107.

Rounds, M.A., and Nielsen, S.S. (1993). Anion-exchange high-performance liquid chromatography with post-column detection for the analysis of phytic acid and other inositol phosphates. Journal of Chromatography A 653: 148-152.

Sandberg, A.-S., and Ahderinne, R. (1986). HPLC method for determination of inositol tri-, tetra-, penta-, and hexaphosphates in foods and intestinal contents. Journal of Food Science 51: 547-550.

Sandberg, A.-S., Brune, M., Carlsson, N.-G., Hallberg, L., Skoglund, E., and Rossander-Hulthén, L. (1999). Inositol phosphates with different numbers of phosphate groups influence iron absorption in humans. The American Journal of Clinical Nutrition 70: 240-246.

Sandström, B., Almgren, A., Kivistö, B., and Cederblad, Å. (1989). Effect of protein level and protein source on zinc absorption in humans. Journal of Nutrition 119: 48-53.

Sasakawa, N., Sharif, M., and Hanley, M.R. (1995). Metabolism and biological activities of inositol pentakisphosphate and inositol hexakisphosphate. Biochemical Pharmacology 50: 137-146.

Sauer, K., and Cooke, M.P. (2010). Regulation of immune cell development through solubleinositol-1,3,4,5-tetrakisphosphate. Nature Reviews Immunology 10: 257-271.

Schlemmer, U., Frólich, W., Prieto, R.M., and Grases, F. (2009). Phytate in foods and significance for humans: Food sources, intake, processing, bioavailability, protective role and analysis. Molecular Nutrition \& Food Research 53: S330-S375.

Selle, P.H., Ravindran, V., Caldwell, A., and Bryden, W.L. (2000). Phytate and phytase: consequences for protein utilisation. Nutrition Research Reviews 13: 255-278.

Shamsuddin, A.M., Ullah, A., and Chakravarthy, A.K. (1989). Inositol and inositol hexaphosphate suppress cell proliferation and tumor formation in CD-1 mice. Carcinogenesis 10: 1461-1463.

Shamsuddin, A.M., and Yang, G.-Y. (1995). Inositol hexaphosphate inhibits growth and induces differentiation of PC-3 human prostate cancer cells. Carcinogenesis 16: 1975-1979.

Shears, S.B. (1998). The versatility of inositol phosphates as cellular signals. Biochimica et Biophysica Acta 1436: 49-67.

Shelor, C.P., Liao, H., Kadjo, A.F., and Dasgupta, P.K. (2015). Enigmatic ionexchange behavior of myo-inositol phosphates. Analytical Chemistry 87: 4851-4855.

Siegenberg, D., Baynes, R.D., Bothwell, T.H., Macfarlane, B.J., Lamparelli, R.D., Car, N.G., MacPhail, P., Schmidt, U., Tal, A., and Mayet, F. (1991). Ascorbic acid prevents the dose-dependent inhibitory effects of polyphenols and phytates on nonheme-iron absorption. The American Journal of Clinical Nutrition 53: 537-541.

Silva, E.O., Gerez, J.R., and Bracarense, A.P.F.R.L. (2014a). Effect of phytic acid from rice and corn on morphology, cell proliferation, apoptosis and cyclooxygenase-2 expression in swine jejunal explants. Ciência e Agrotecnologia 38: 278-285.

Silva, E.O., Gerez, J.R., Drape, T.C., and Bracarense, A.P.F.R.L. (2014b). Phyt- 
ic acid decreases deoxynivalenol and fumonisin B1-induced changes on swine jejunal explants. Toxicology Reports 1: 284-292.

Simonet, B.M., Ríos, A., Grases, F., and Valcárcel, M. (2003). Determination of myo-inositol phosphates in food samples by flow injection-capillary zone electrophoresis. Electrophoresis 24: 2092-2098.

Simpson, K.M., Morris, E.R., and Cook, J.D. (1981). The inhibitory effect of bran on iron absorption in man. The American Journal of Clinical Nutrition 34: 1469-1478.

Simwemba, C.G., Hoseney, R.C., Varriano-Marston, E., and Zeleznak, K. (1984). Certain B vitamin and phytic acid contents of pearl millet [Pennisetum americanum (L.) Leeke]. Journal of Agricultural and Food Chemistry 32: 31-34.

Singh, B., and Sedeh, H.G. (1979). Characteristics of phytase and its relationship to acid phosphatase and certain mineral in triticale. Cereal Chemistry 56: 267-272.

Singh, R.P., Agarwal, C., and Agarwal, R. (2003). Inositol hexaphosphate inhibits growth, and induces $\mathrm{G} 1$ arrest and apoptotic death of prostate carcinoma DU145 cells: modulation of CDKI-CDK-cyclin and pRbrelated protein-E2F complexes. Carcinogenesis 24: 555-563.

Sjöberg, P.J.R., Theline, P., and Rydin, E. (2016). Separation of inositol phosphate isomers in environmental samples by ion-exchange chromatography coupled with electrospray ionization tandem mass spectrometry. Talanta 161: 392-397.

Smith, D.H., and Clark, F.E. (1952). Chromatographic separations of inositol phosphorus compounds. Soil Science Society of America Journal 16: $170-172$.

Smith, R.E., and MacQuarrie, R.A. (1988). Determination of inositol phosphates and other biologically important anions by ion chromatography. Analytical Biochemistry 170: 308-315.

Steiner, T., Mosenthin, R., Zimmermann, B., Greiner, R., and Roth, S. (2007). Distribution of phytase activity, total phosphorus and phytate phosphorus in legume seeds, cereals and cereal by-products as influenced by harvest year and cultivar. Animal Feed Science and Technology 133: 320-334.

Stodolak, B., Starzyńska, A., Czyszczoń, M., and Żyła, K. (2007). The effect of phytic acid on oxidative stability of raw and cooked meat. Food Chemistry 101: 1041-1045.

Streb, H., Irvine, R.F., Berridge, M.J., and Schulz, I. (1983). Release of Ca ${ }^{2+}$ from a nonmitochondrial intracellular store in pancreatic acinar cells by inositol-1,4,5-trisphosphate. Nature 306: 3-9.

Talamond, P., Doulbeau, S., Rochette, I., Guyot, J.-P., and Treche, S. (2000). Anion-exchange high-performance liquid chromatography with conductivity detection for the analysis of phytic acid in food. Journal of Chromatography A 871: 7-12.

Tangendjaja, B., Buckle, K., and Wootton, M. (1980). Analysis of phytic acid by high-performance liquid chromatography. Journal of Chromatography 197: 274-277.

Tateishi, H., Anraku, K., Koga, R., Okamoto, Y., Fujita, M., and Otsuka, M. (2014). Design and synthesis of lipid-coupled inositol 1,2,3,4,5,6-hexakisphosphate derivatives exhibiting high-affinity binding for the HIV1 MA domain. Organic \& Biomolecular Chemistry 12: 5006-5022.

Taylor, G.S., Garcia, J.G.N., Dukes, R., and English, D. (1990). High-performance liquid chromatographic analysis of radiolabeled inositol phosphates. Analytical Biochemistry 188: 118-122.

Tsao, G.T., Zheng, Y., Lu, J., and Gong, C.S. (1997). Adsorption of heavy metal ions by immobilized phytic acid. Applied Biochemistry and Biotechnology.63-65: 731-741.

Tsubokawa, H., Oguro, K., Robinson, H.P.C., Masuzawa, T., and Kawai, N. (1996). Intracellular inositol 1,3,4,5-tetrakisphosphate enhances the calcium current in hippocampal CA1 neurones of the gerbil after ischaemia. Journal of Physiology 497: 67-78.
Vajanaphanich, M., Schultz, C., Rudolf, M.T., Wasserman, M., Enyedi, P., Craxton, A., Shears, S.B., Tsien, R.Y., Barrett, K.E., and Traynor-Kaplan, A. (1994). Long-term uncoupling of chloride secretion from intracellular calcium levels by $\operatorname{lns}(3,4,5,6) \mathrm{P}_{4}$. Nature $371: 711-714$.

Vasca, E., Materazzi, S., Caruso, T., Milano, O., Fontanella, C., and Manfredi, C. (2002). Complex formation between phytic acid and divalent metal ions: a solution equilibria and solid state investigation. Analytical and Bioanalytical Chemistry 374: 173-178.

Venkatachalam, M., and Sathe, S.K. (2006). Chemical composition of selected edible nut seeds. Journal of Agricultural and Food Chemistry 54: 4705-4714

Vucenik, I., Passaniti, A., Vitolo, M.I., Tantivejkul, K., Eggleton, P., and Shamsuddin, A.M. (2004). Anti-angiogenic activity of inositol hexaphosphate $\left(\mathrm{IP}_{6}\right)$. Carcinogenesis 25: 2115-2123.

Vucenik, I., and Shamsuddin, A.M. (1994). $\left[{ }^{3} \mathrm{H}\right]$ Inositol hexaphosphate (phytic acid) is rapidly absorbed and metabolized by murine and human malignant cells in vitro. Journal of Nutrition 124: 861-868.

Vucenik, I., and Shamsuddin, A.M. (2006). Protection against cancer by dietary $I P_{6}$ and inositol. Nutrition and Cancer 55: 109-125.

Vucenik, I., Yang, G.-Y., and Shamsuddin, A.M. (1995). Inositol hexaphosphate and inositol inhibit DMBA-induced rat mammary cancer. Carcinogenesis 16: 1055-1058.

Walter, A., Rimbach, G., Most, E., and Pallauf, J. (2000). Effect of calcium supplements to a maize-soya diet on the bioavailability of minerals and trace elements and the accumulation of heavy metals in growing rats. Journal of Veterinary Medicine A 47: 367-377.

Wang, I.C., Mitchell, H.L., and Barham, H.N. (1959). The phytin content of sorghum grain. Transactions of the Kansas Academy of Science 62: 208-211.

Williams, S.P., Gillaspy, G.E., and Perera, I.Y. (2015). Biosynthesis and possible functions of inositol pyrophosphates in plants. Frontiers in Plant Science 6: 1-12.

Wilson, M.S.C., Bulley, S.J., Pisani, F., Irbine, R.F., and Saiardi, A. (2015). A novel method for the purification of inositol phosphates from biological samples reveals that no phytate is present in human plasma or urine. Open Biology 5: 1-8.

Wilson, M.S.C., Livermore, T.M., and Saiardi, A. (2013). Inositol pyrophosphates: Between signalling and metabolism. Biochemical Journal 452: 369-379.

World Health Organization. (2014). Zinc, folate, vitamin B12 and other B vitamins, vitamin $C$, vitamin $D$, calcium, selenium and fluoride. In: Guidelines on food fortification with micronutrients, p. 57-60, WHO Press, Geneva, Switzerland.

Xu, Q., Kanthasamy, A.G., and Reddy, M.B. (2008). Neuroprotective effect of the natural iron chelator, phytic acid in a cell culture model of Parkinson's disease. Toxicology 245: 101-108.

Zdunczyk, Z., Godycka, I., and Amarowicz, R. (1997). Chemical composition and content of antinutritional factors in Polish cultivars of peas. Plant Foods for Human Nutrition 50: 37-45.

Zhang, Z., Song, Y., and Wang, X.L. (2005). Inositol hexaphosphate-induced enhancement of natural killer cell activity correlates with suppression of colon carcinogenesis in rats. World Journal of Gastroenterology 11: 5044-5046.

Zhang, S., Yang, W., Zhao, Q., Zhou, X., Fan, Y., and Chen, R. (2017). Rapid method for simultaneous determination of inositol phosphates by IPC-ESI-MS/MS and its application in nutrition and genetic research. Chromatographia 80: 275-286.

Zhuang, T., Vishnivetskiy, S.A., Gurevich, V.V., and Sanders, C.R. (2010). Elucidation of inositol hexaphosphate and heparin interaction sites and conformational changes in arrestin-1 by solution nuclear magnetic resonance. Biochemistry 49: 10473-10485. 